Nevada

DOE/NV--905

Environmental

Restoration

Project

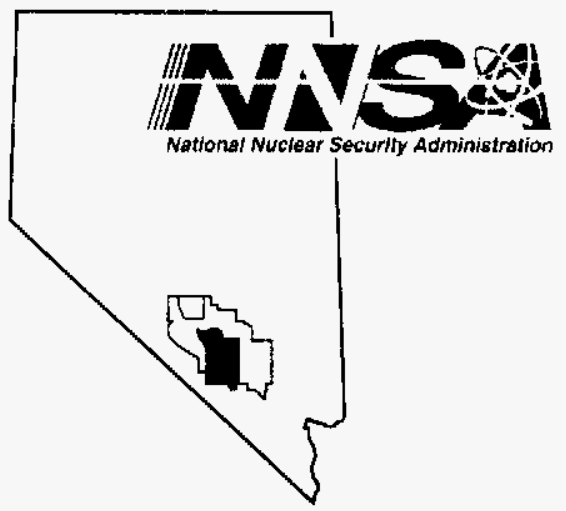

Corrective Action Plan for

Corrective Action Unit 271: Areas

25, 26, and 27 Septic Systems

Nevada Test Site, Nevada

Controlled Copy No.:

Revision: 0

May 2003

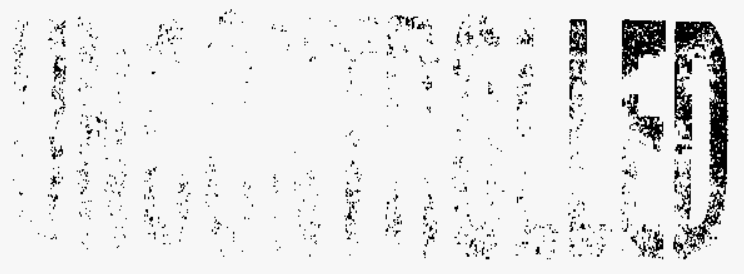




\section{DISCLAIMER STATEMENT}

Reference herein to any specific commercial product, process, or service by trade name, trademark, manufacturer, or otherwise, does not necessarily constitute or imply its endorsement, recommendation, or favoring by the U.S. Government or any agency thereof or its contractors or subcontractors.

\section{AVAILABILITY STATEMENT}

Available for sale to the public from-

U.S. Department of Commerce

National Technical Information Service

5285 Port Royal Road

Springfield, VA 22161-0002

Telephone: 800.553 .6847

Fax: 703.605.6900

E-mail: orders@ntis.fedworld.gov

Online ordering: http://www.ntis.gov/ordering.htm

Available electronically at http://www.doe.gov/bridge

Available for a processing fee to U.S. Department of Energy and its contractors, in paper, from-

U.S. Department of Energy

Office of Scientific and Technical Information

P.O. Box 62

Oak Ridge, TN 37831-0062

Telephone: 865.576 .8401

Fax: 865.576 .5728

E-mail: reports@adonis.osti.gov 


\title{
CORRECTIVE ACTION PLAN FOR CORRECTIVE ACTION UNIT 271: AREAS 25, 26, AND 27 SEPTIC SYSTEMS, NEVADA TEST SITE, NEVADA
}

\author{
Prepared for: \\ U.S. Department of Energy \\ National Nuclear Security Administration \\ Nevada Site Office \\ Under Contract No. DE-AC08-96NV11718
}

Controlled Copy No.

Revision: 0

May 2003 
THIS PAGE INTENTIONALLY LEFT BLANK 


\section{CORRECTIVE ACTION PLAN FOR CORRECTIVE ACTION UNIT 271: AREAS 25, 26, AND 27 SEPTIC SYSTEMS, NEVADA TEST SITE, NEVADA}
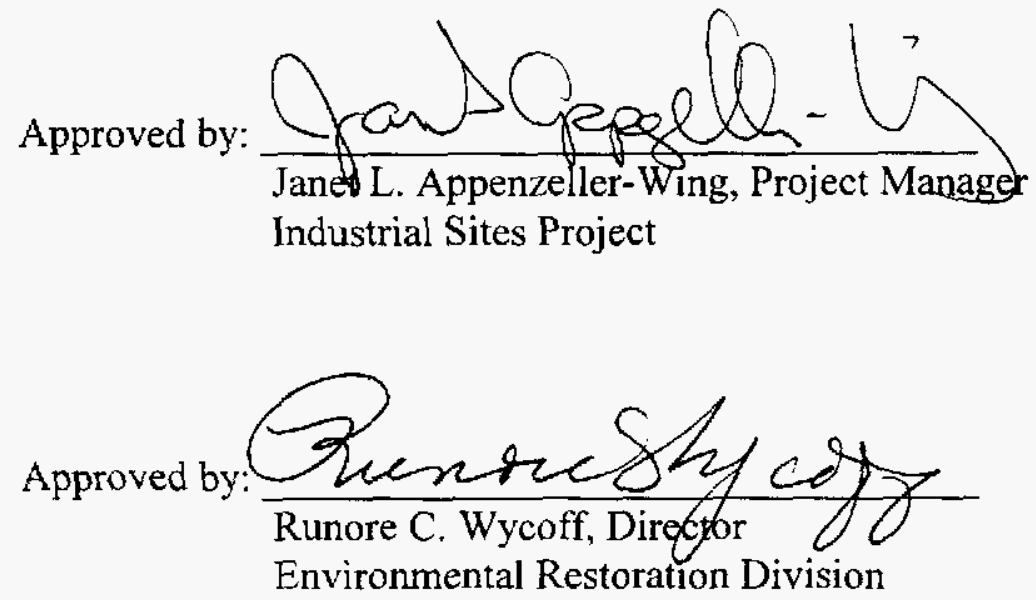

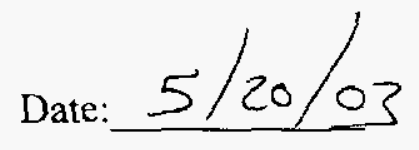

Date: $5 / 20 / 03$ 
THIS PAGE INTENTIONALLY LEFT BLANK 


\section{TABLE OF CONTENTS}

ACRONYMS AND ABBREVIATIONS $\ldots \ldots \ldots \ldots \ldots \ldots \ldots \ldots \ldots \ldots \ldots$ ix

EXECUTIVE SUMMARY $\ldots \ldots \ldots \ldots \ldots \ldots \ldots \ldots \ldots \ldots \ldots \ldots \ldots \ldots \ldots \ldots$

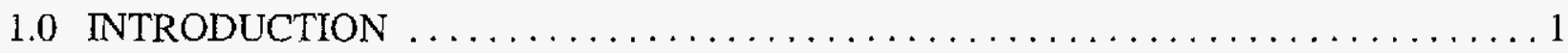

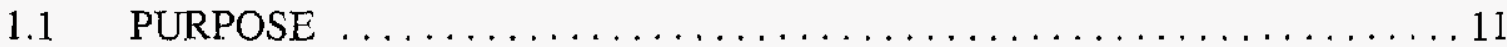

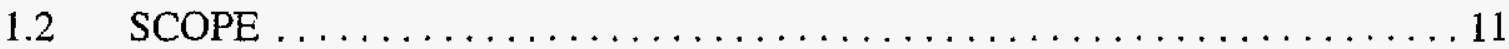

1.3 CORRECTIVE ACTION PLAN CONTENTS $\ldots \ldots \ldots \ldots \ldots \ldots \ldots \ldots \ldots 1$

2.0 DETALED STATEMENT OF WORK $\ldots \ldots \ldots \ldots \ldots \ldots \ldots \ldots \ldots \ldots \ldots$

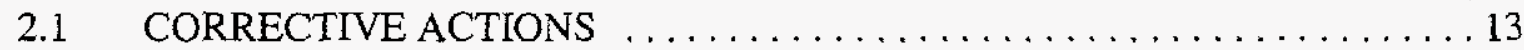

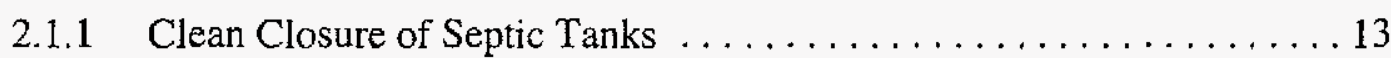

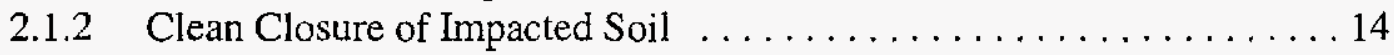

2.1.3 Clean Closure of Contaminated Manholes . . . . . . . . . . . . . . 15

2.1.4 Clean Closure of Distribution Boxes ................. 16

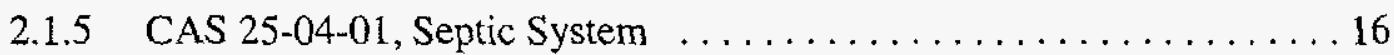

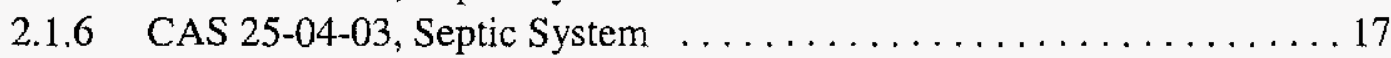

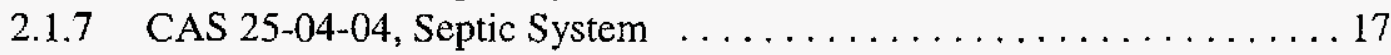

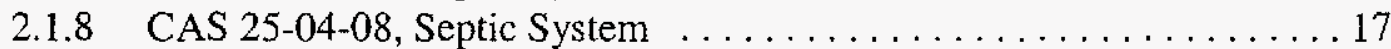

2.1.9 CAS 25-04-09, Septic System ... . . . . . . . . . . . . . 19

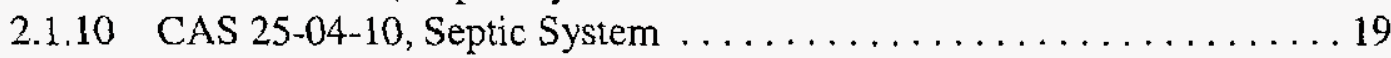

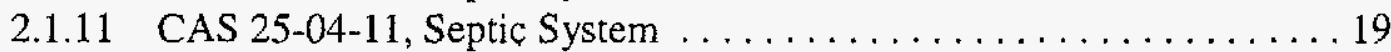

2.1.12 CAS 26-03-01, Contaminated Water Reservoir . . . . . . . . . 21

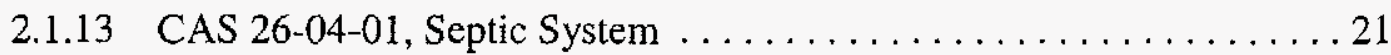

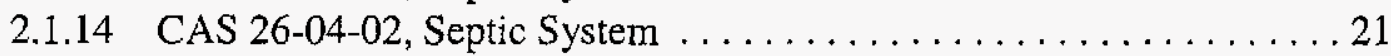

2.1.15 CAS 26-05-01, Radioactive Leachfield ................. 21

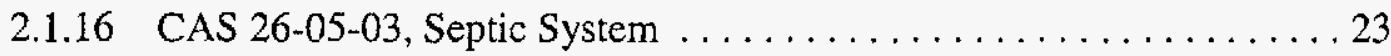

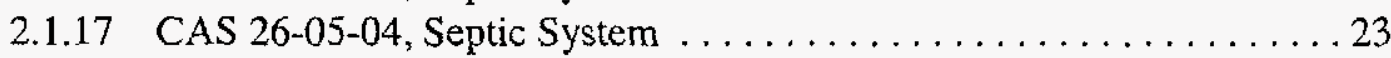

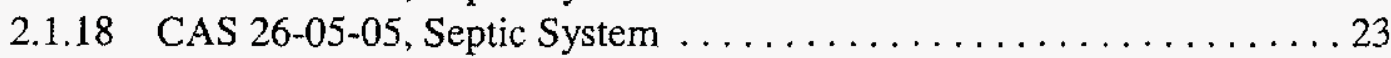

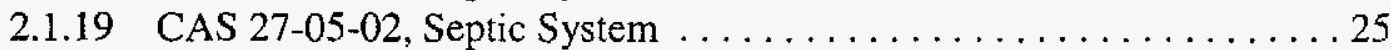

2.2 CONSTRUCTION QUALITY ASSURANCE/QUALITY CONTROL $\ldots \ldots .27$

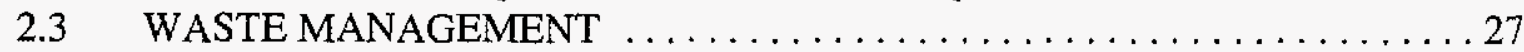

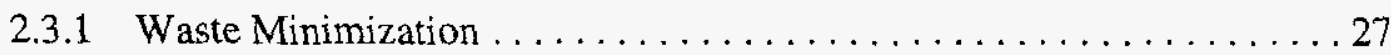

2.3 .2 Waste Streams . . . . . . . . . . . . . . . . . . . . 28

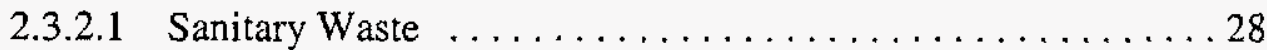

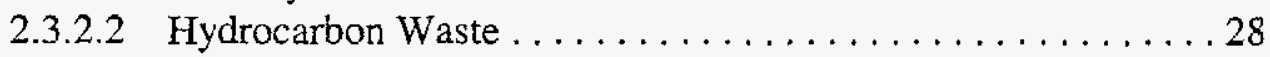

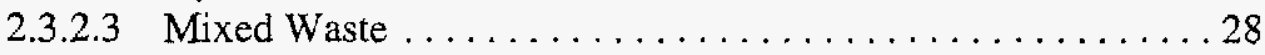

2.3.2.4 Low-Level Radioactive Waste $\ldots \ldots \ldots \ldots \ldots \ldots \ldots \ldots . \ldots \ldots$

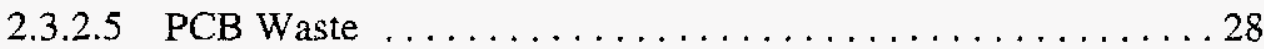

2.3.2.6 Hazardous Waste . . . . . . . . . . . . . . . . . . . 29

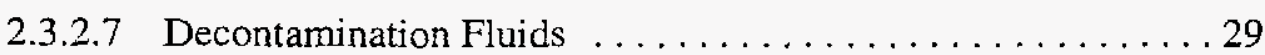

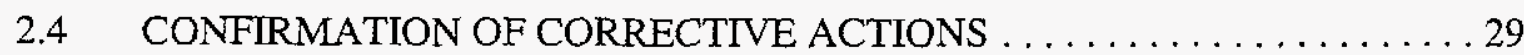

2.5 PERMITS, PLANNING, AND SITE PREPARATION $\ldots \ldots \ldots \ldots \ldots \ldots . \ldots$ 


\section{TABLE OF CONTENTS (continued)}

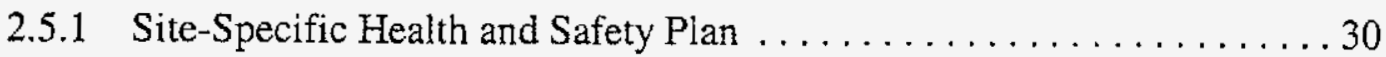

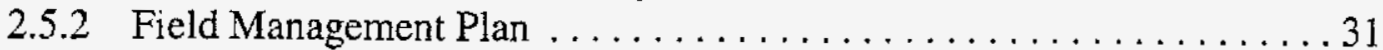

2.5.3 National Environmental Policy Act Checklist . . . . . . . . . . . 31

2.5.4 NNSA/NSO Real Estate/Operations Permit $\ldots \ldots \ldots \ldots \ldots \ldots \ldots . \ldots 31$

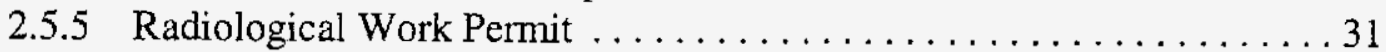

2.5.6 Utility Clearances and Excavation Permits ............. 31

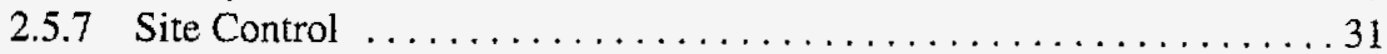

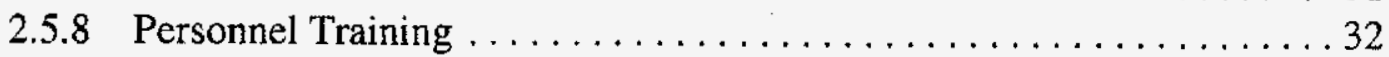

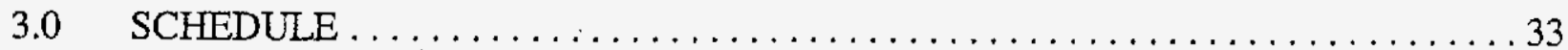

4.0 POST-CLOSURE MONITORING PLAN $\ldots \ldots \ldots \ldots \ldots \ldots \ldots \ldots \ldots \ldots \ldots$

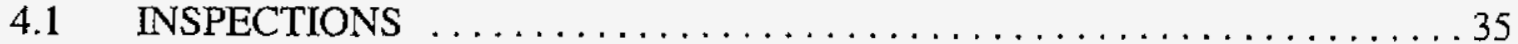

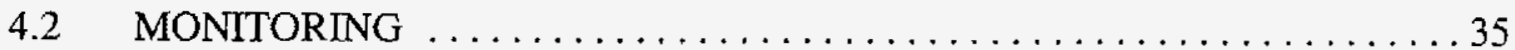

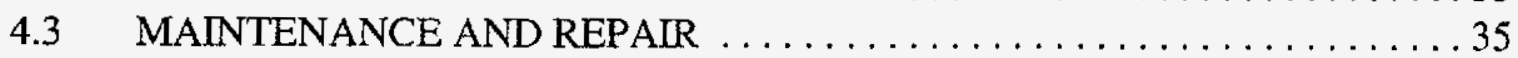

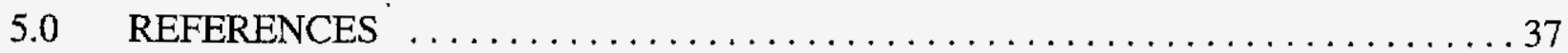

\section{FIGURES}

FIGURE 1 - CAU 271 SITE LOCATION MAP $\ldots \ldots \ldots \ldots \ldots \ldots \ldots \ldots \ldots \ldots \ldots$

FIGURE 2 - CAU 271 CASs IN AREA 25 OF THE NEVADA TEST SITE $\ldots \ldots \ldots \ldots \ldots$.

FIGURE 3 - CAU 271 CASs IN AREA 26 OF THE NEVADA TEST SITE $\ldots \ldots \ldots \ldots \ldots 4$

FIGURE 4 - CAU 271 CAS IN AREA 27 OF THE NEVADA TEST SITE $\ldots \ldots \ldots \ldots \ldots \ldots 5$

FIGURE 5 - LOCATION OF TPH IMPACTED SOIL AT CAS $25-04-04 \ldots \ldots \ldots \ldots$

FIGURE 6 - LOCATION OF PLUTONTUM 239 IMPACTED SOIL AT CAS 25-04-08 . . . 20

FIGURE 7 - LOCATION OF RADIOLOGICALLY CONTAMINATED SOIL AT

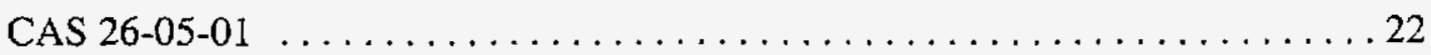

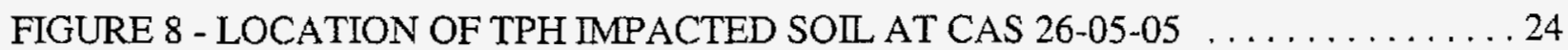

FIGURE 9 - LOCATION OF PCB IMPACTED SOL AT CAS $27-05-02 \ldots \ldots \ldots$

FIGURE 10 - CAU 271 PROPOSED CLOSURE SCHEDULE . . . . . . . . . . . 34 


\section{TABLE OF CONTENTS (continued)}

\section{TABLES}

TABLE 1 - GENERAL CLOSURE STRATEGY FOR CAU $271 \ldots \ldots \ldots \ldots$

\section{APPENDICES}

APPENDIX A.1 - ENGINEERING SPECIFICATIONS AND DRAWINGS

APPENDIX A.2 - SAMPLING AND ANALYSIS PLAN

APPENDIX A.3 - PROJECT ORGANIZATION

APPENDIX B - NEVADA DIVISION OF ENVIRONMENTAL PROTECTION DOCUMENT REVIEW SHEET

DISTRIBUTION LIST 
CAP $\cdot$ CAU 271

Section: Table of Contents

Revision: ()

Date: May 2003

THIS PAGE INTENTIONALLY LEFT BLANK 


\section{ACRONYMS AND ABBREVIATIONS}

\begin{tabular}{|c|c|}
\hline $\mathrm{BN}$ & Bechtel Nevada \\
\hline BREN & Bare Reactor Experiment-Nevada \\
\hline CADD & Corrective Action Decision Document \\
\hline CAIP & Corrective Action Investigation Plan \\
\hline CAP & Corrective Action Plan \\
\hline CAS & Corrective Action Site \\
\hline CAU & Corrective Action Unit \\
\hline $\mathrm{COC}$ & Contaminant(s) of Concern \\
\hline $\mathrm{CR}$ & Closure Report \\
\hline $\mathrm{DQO}$ & Data Quality Objective \\
\hline EPA & U.S. Environmental Protection Agency \\
\hline ER & Environmental Restoration \\
\hline ETS & Engine Test Stand \\
\hline $\mathrm{EZ}$ & Exclusion Zone \\
\hline FFACO & Federal Facility Agreement and Consent Order \\
\hline FMP & Field Management Plan \\
\hline $\mathrm{ft}$ & foot(feet) \\
\hline gal & gallon(s) \\
\hline HSO & Health and Safety Officer \\
\hline HW & Hazardous Waste \\
\hline ISOCS & In-Situ Object Counting System \\
\hline $\mathrm{km}$ & kilometer(s) \\
\hline $\mathrm{L}$ & liter(s) \\
\hline LDR & Land Disposal Restrictions \\
\hline LLW & Low-Level Waste \\
\hline $\mathrm{m}$ & meter(s) \\
\hline $\mathrm{m}^{3}$ & cubic meter(s) \\
\hline $\mathrm{mg} / \mathrm{kg}$ & milligram per kilogram \\
\hline $\mathrm{mi}$ & mile(s) \\
\hline NAC & Nevada Administrative Code \\
\hline
\end{tabular}




\section{ACRONYMS AND ABBREVIATIONS (continued)}

NEPA National Environmental Policy Act

NNSA/NSO U.S. Department of Energy, Nationa! Nuclear Security Administration Nevada Site Office

NNSA/NV U.S. Department of Energy, National Nuclear Security Administration Nevada Operations Office

NTS Nevada Test Site

OI Organization Instruction

OP Organization Procedure

PCB polychlorinated biphenyl(s)

PPE Personal Protective Equipment

QA Quality Assurance

QC Quality Control

RCP Reactor Control Point

RCRA Resource Conservation and Recovery Act

REOP Real Estate/Operations Permit

RWP Radiological Work Permit

SSHASP Site-Specific Health and Safety Plan

SVOC semi volatile organic Compound(s)

TCLP Toxicity Characterization Leaching Procedure

$\mathrm{TPH} \quad$ total petroleum hydrocarbons

TSD Treatment, Storage, and Disposal Facility

WAA Waste Accumulation Area

$\mathrm{yd}^{3} \quad$ cubic yard(s)

VOC volatile organic compound(s) 


\section{EXECUTIVE SUMMARY}

The Areas 25, 26 and 27 Septic Systems are identified in the Federal Facility Agreement and Consent Order (FFACO) of 1996 as Corrective Action Unit (CAU) 271. CAU 271 is located on the Nevada Test Site (NTS) approximately 105 kilometers (65 miles) northwest of Las Vegas, Nevada, and consists of the following 15 corrective Action Sites (CAS):

- $\quad$ CAS 25-04-01, Septic System
- $\quad$ CAS 25-04-03, Septic System
- $\quad$ CAS 25-04-04, Septic System
- $\quad$ CAS 25-04-08, Septic System
- $\quad$ CAS 25-04-10, Septic System
- $\quad$ CAS 25-04-11, Septic System
- $\quad$ CAS 26-03-01, Contaminated Water Reservoir
- $\quad$ CAS 26-04-01, Septic System
- $\quad$ CAS 26-04-02, Septic System 26-05-01, Radioactive Leachfield
- $\quad$ CAS 26-05-03, Septic System
- $\quad$ CAS 26-05-04, Septic System
- $\quad$ CAS 26-05-05, Septic System
- $\quad$ CAS 27-05-02, Leachfield

CAU 271 CASs in Area 25 of the NTS are located near Guard Station 500, the Reactor Control Point, Bare Reactor Experiment-Nevada Tower, and the Engine Test Stand facilities. The CASs in Area 26 are located near the Port Gaston and Pluto Project facilities, and in Area 27 near the Baker Site. CAU 271 CASs are comprised of septic systems, leachfields, and a contaminated water reservoir. Septic systems include any piping, septic tanks, and diversion structures or distribution boxes between the edge of the source building foundation and the distribution system. During operation, these septic systems and leachfields received a significant quantity of process and sanitary effluent during routine operations.

CAU 271 was previously characterized by the International Technology Corporation, Las Vegas office. Site characterization results were presented in the Corrective Action Decision Document (CADD) for CAU 271, Area 25, 26, and 27 Septic Systems (U.S. Department of Energy, National Nuclear Security Administration Nevada Operations Office [NNSA/NV], 2002). Site characterization data indicated that the contents of some septic tanks, distribution boxes, manholes, and the soil within the boundaries of the leachfields exceeded clean-up criteria for total petroleum hydrocarbons, polychlorinated biphenyls, pesticides, and radionuclides.

The following 12 CASs contain septic tanks impacted with contaminants of concern (COC) and will be closed by Corrective Action Altemative 2 - Clean Closure. The contents of the tank will be removed and properly disposed. If feasible the tank will be removed from the ground and the excavation will be backfilled with clean fill. If a septic tank can not be easily removed due to its 
size or other factors, it will be cleaned and filled with an inert material.

- CAS 25-04-01, Septic System

- CAS 25-04-03, Septic System

- CAS 25-04-04, Septic System

- CAS 25-04-08, Septic System

- CAS 25-04-09, Septic System

- CAS 25-04-11, Septic System

- CAS 26-04-01, Septic System

- CAS 26-04-02, Septic System

- CAS 26-05-03, Septic System

- CAS 26-05-04, Septic System

- CAS 26-05-05, Septic System

- CAS 27-05-02, Leachfield

The following Six CASs contain COC impacted soil and will be closed by Corrective Action Alternative 2 - Clean Closure. The impacted soil will be removed by excavation and disposal.

- CAS 25-04-04, Septic System

- CAS 25-04-08, Septic System

- CAS 26-03-01, Contaminated Water Reservoir

- CAS 26-05-01, Radioactive Leachfield

- CAS 26-05-05, Septic System

- CAS 27-05-02, Leachfield

The following three CASs contain manholes impacted with COC and will be closed by Corrective Action Alternative 2 - Clean Closure. The contents of the manhole will be removed and properly disposed. If feasible the manhole will be removed from the ground and the excavation will be backfilled with clean fill. If the manhole can not be easily removed due to its size or other factors, it will be cleaned and filled with an inert material.

- CAS 25-04-11, Septic System

- CAS 26-05-01, Radioactive Leachfield

- CAS 26-05-03, Septic System

CAS 25-04-10, Septic System does not contain any COC and will be closed by Corrective Action Alternative 1 - No Further Action, but as a best management practice the septic tank will be filled with an inert material.

All distribution boxes identified in the CADD (NNSA/NV, 2002) requiring clean closure will be closed by either removing the contents and distribution box or filling the box with an inert material. 


\subsection{INTRODUCTION}

The Areas 25, 26 and 27 Septic Systems are in the Federal Facility Agreement and Consent Order (FFACO) of 1996 as Corrective Action Unit (CAU) 271. This Corrective Action Plan (CAP) provides selected corrective action aiternatives and proposes the closure methodology for CAU 271. CAU 271 is located on the Nevada Test Site (NTS) approximately 105 kilometers $(\mathrm{km})$ (65 miles [mi]) northwest of Las Vegas, Nevada, and consists of the following 15 Corrective Action Sites (CAS) (Figure 1):

- $\quad$ CAS 25-04-01, Septic System
- $\quad$ CAS 25-04-03, Septic System
- $\quad$ CAS 25-04-04, Septic System 25-04-08, Septic System
- $\quad$ CAS 25-04-09, Septic System
- $\quad$ CAS 25-04-10, Septic System
- $\quad$ CAS 25-04-11, Septic System
- $\quad$ CAS 26-03-01, Contaminated Water Reservoir
- $\quad$ CAS 26-04-01, Septic System
- $\quad$ CAS 26-05-01, Septic System
- $\quad$ CAS 26-05-03, Septic System
- $\quad$ CAS 26-05-04, Septic System
- $\quad$ CAS 27-05-02, Septic System

CAU 271 CASs in Area 25 of the NTS are located in the vicinity of Guard Station 500, the Reactor Control Point (RCP), Bare Reactor Experiment-Nevada (BREN) Tower, and the Engine Test Stand (ETS) facilities (Figure 2). The CASs in Area 26 are located near the Port Gaston and Pluto Project facilities (Figure 3), and in Area 27 near the Baker Site (Figure 4). CAU 271 CASs are comprised of septic systems, leachfields, and a contaminated water reservoir. Septic systems include any piping, septic tanks, and diversion structures or distribution boxes between the edge of the source building foundation and the distribution system. During operation, these septic systems and leachfields received a significant quantity of process and sanitary effluent during routine operations.

Site characterization results and suggested corrective actions were presented in the Corrective Action Decision Document (CADD) for CAU 271, Area 25, 26, and 27 Septic Systems (U.S. Department of Energy, National Nuclear Security Administration Nevada Operations Office [NNSA/NV], 2002).

Table 1 shows the general closure strategy for CAU 271. 


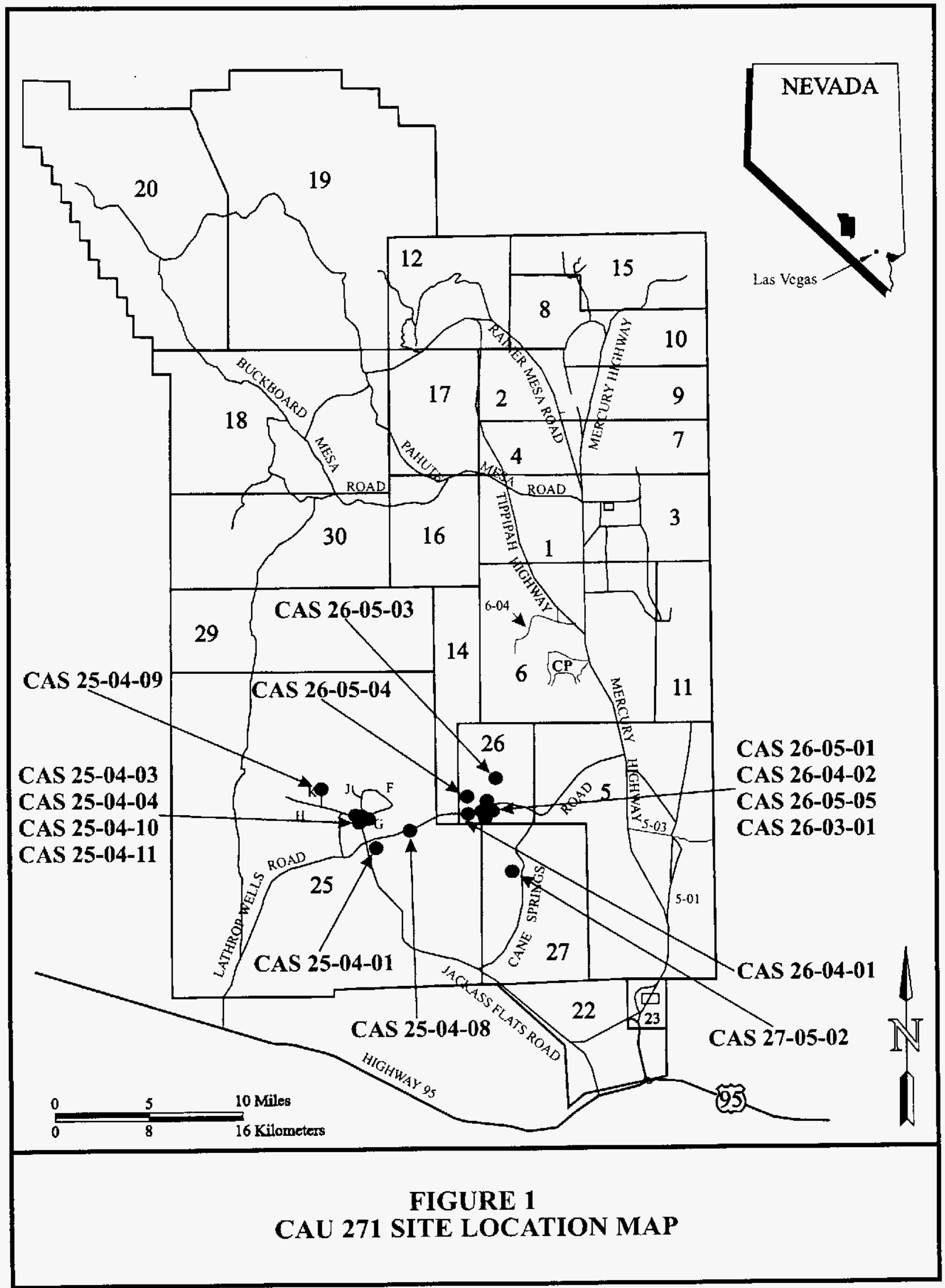




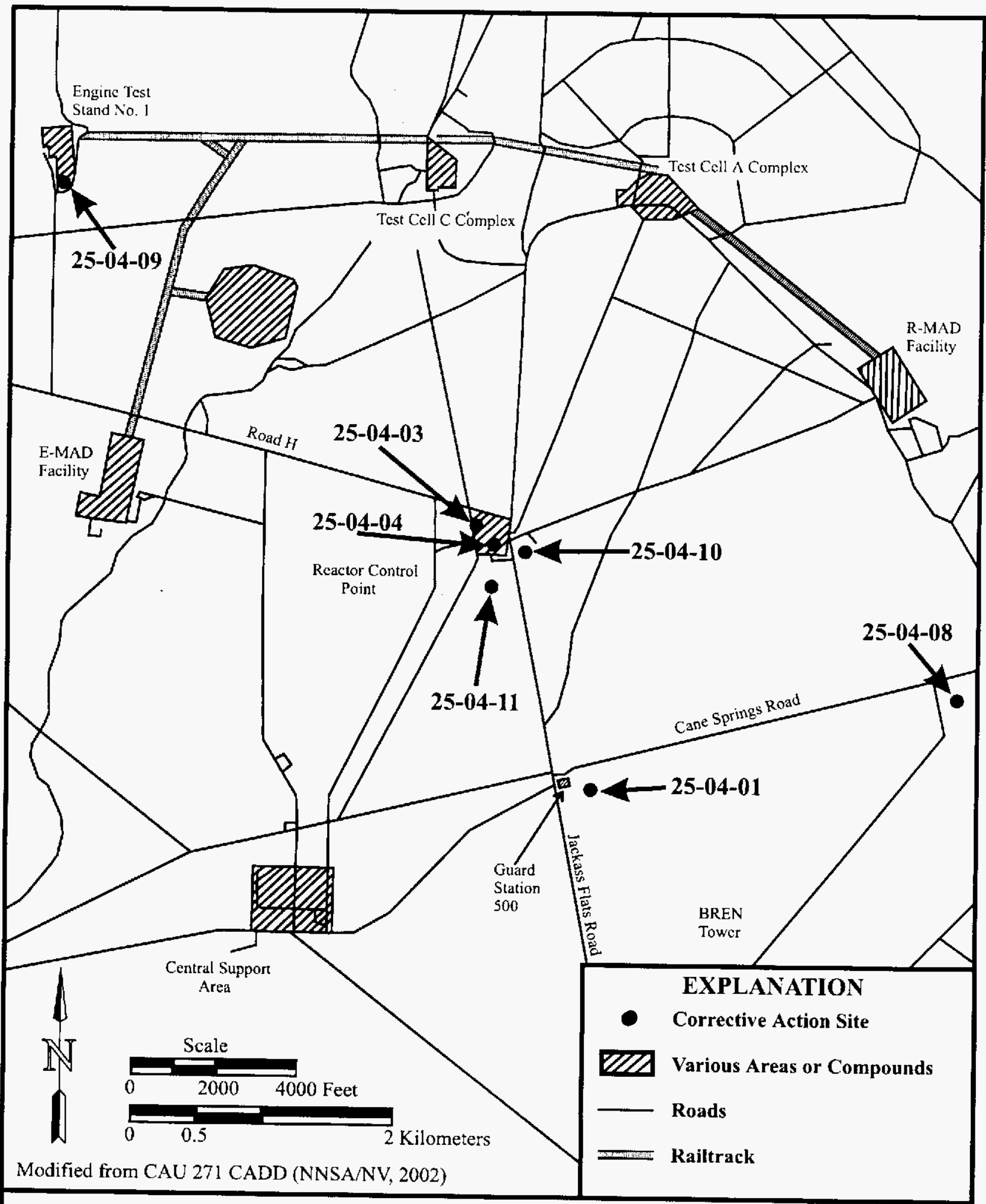

FIGURE 2

CAU 271 CASs IN AREA 25 OF THE NEVADA TEST SITE 


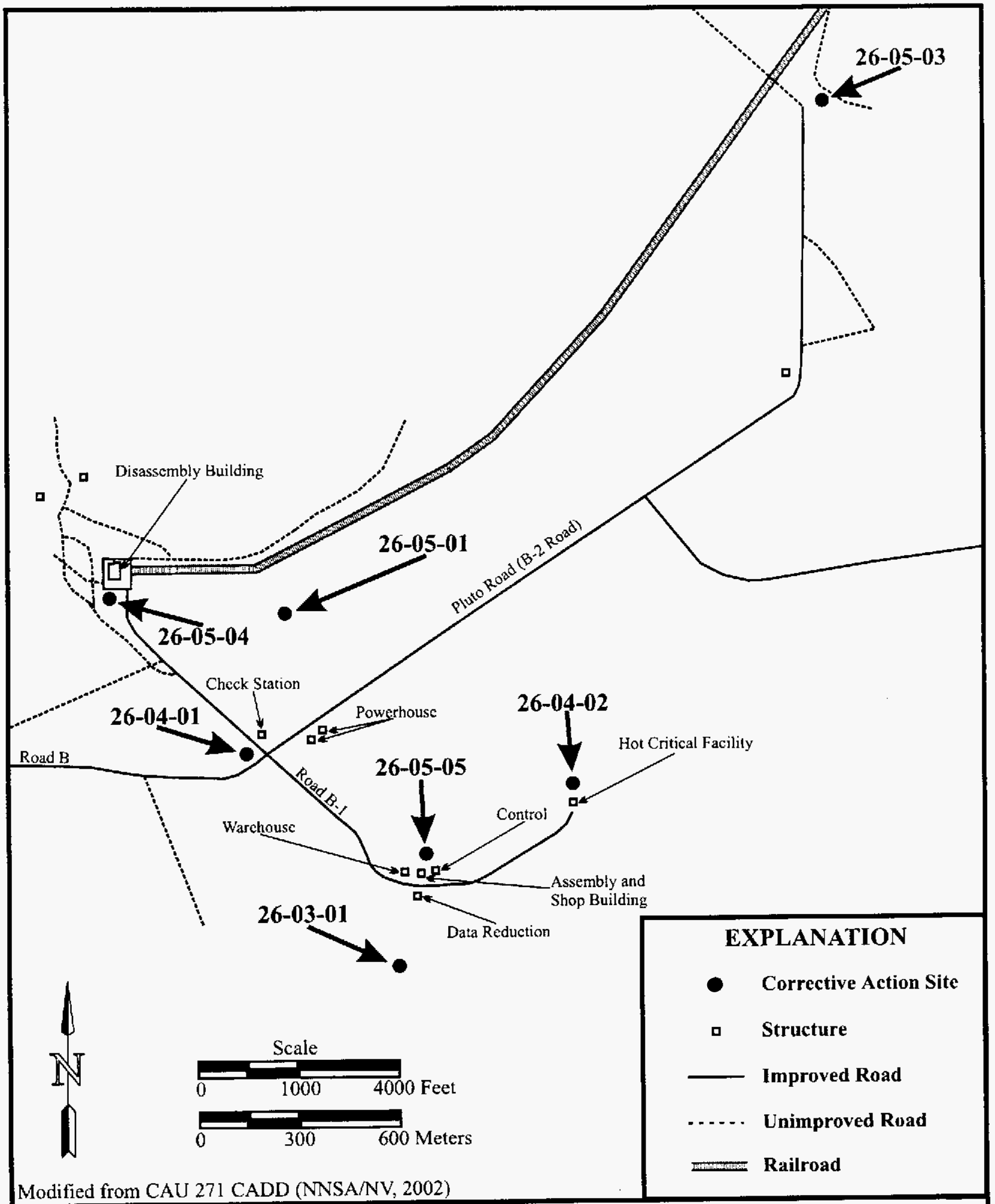

FIGURE 3

CAU 271 CASs IN AREA 26 OF THE NEVADA TEST SITE 


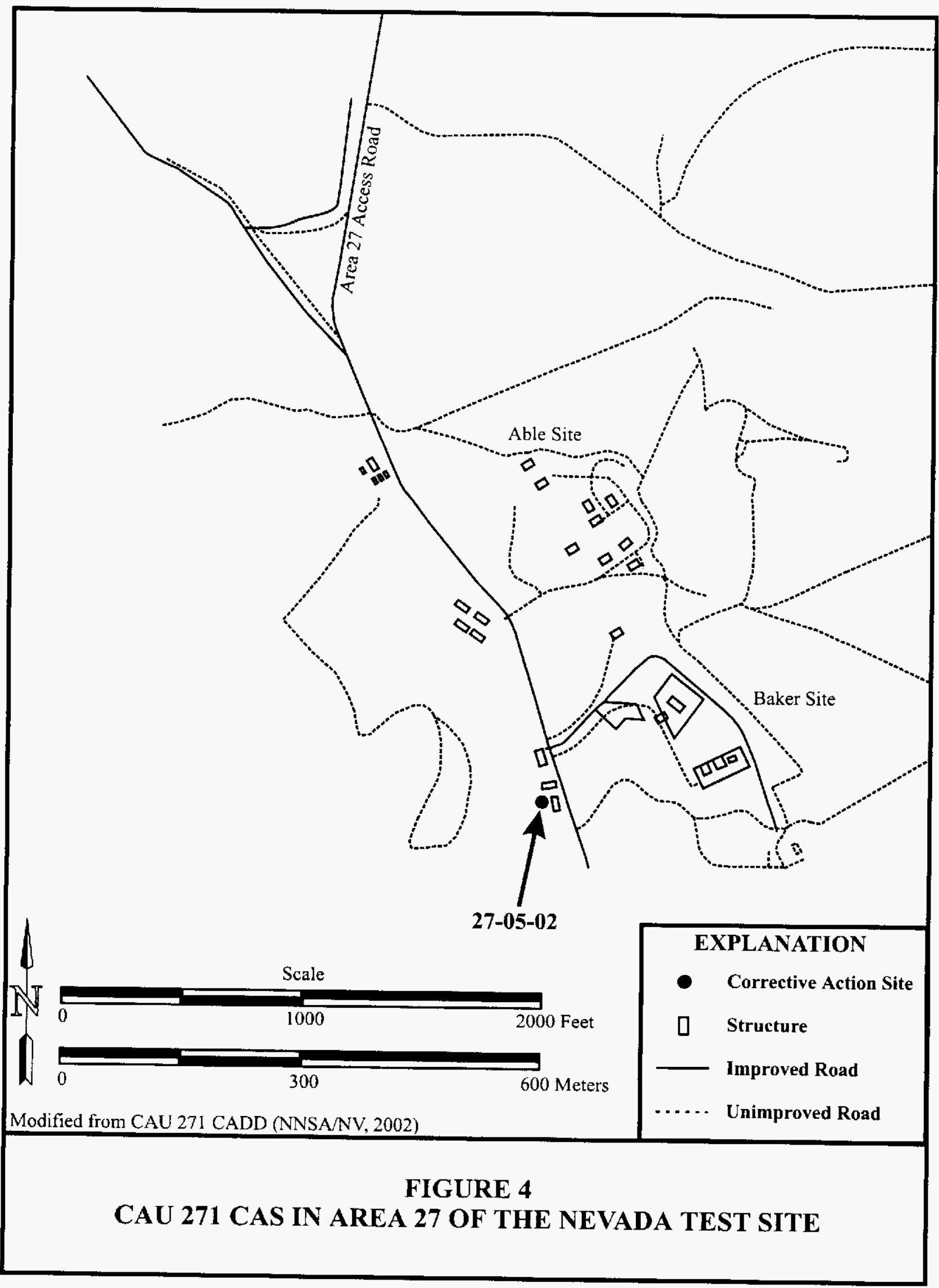


TABLE 1 - GENERAL CLOSURE STRATEGY FOR CAU 271

\begin{tabular}{|c|c|c|c|}
\hline CAS & Location & $\begin{array}{c}\text { Contaminants of } \\
\text { Concern }\end{array}$ & Comments \\
\hline CAS 25-04-01 & $\begin{array}{l}\text { Guard } \\
\text { Station at } \\
\text { Gate } 500\end{array}$ & $\begin{array}{l}\text { TPH (Total Petroleum } \\
\text { Hydrocarbons) }\end{array}$ & $\begin{array}{l}\text { - } \quad \text { Solidify and remove tank contents } \\
\text { Remove tank or rinse and fill with inert } \\
\text { material }\end{array}$ \\
\hline CAS 25-04-03 & $\begin{array}{c}\text { Reactor } \\
\text { Control Point }\end{array}$ & $\begin{array}{c}\text { TPH, Fecal Coliform } \\
\text { Bacteria }\end{array}$ & $\begin{array}{l}\text { Neutralize bacteria } \\
\text { Solidify and remove tank contents } \\
\text { Remove tank or rinse and fill with inert } \\
\text { material }\end{array}$ \\
\hline CAS 25-04-04 & $\begin{array}{c}\text { Reactor } \\
\text { Control Point }\end{array}$ & $\begin{array}{l}\text { TPH, Radionuclides, } \\
\text { Pesticides, Fecal } \\
\text { Coliform Bacteria }\end{array}$ & $\begin{array}{ll}\text { - } & \text { Neutralize bacteria } \\
\text { - } & \text { Solidify and remove tank contents } \\
\text { Remove tank or rinse and fill with inert } \\
\text { material } \\
\text { Remove TPH contaminated soil } \\
\left(\sim 420 \text { cubic yards }\left[y^{3}{ }^{3}\right]\right) \text { near tank } \\
\text { - } \quad \text { Fill distribution box with inert material }\end{array}$ \\
\hline CAS 25-04-08 & BREN Tower & TPH, Radionuclides & $\begin{array}{l}\text { - } \\
\text { Rolidify and remove tank contents } \\
\text { material } \\
\text { Remove Radionuclide contaminated soil } \\
\left(\sim 3 \mathrm{yd}^{3}\right) \text { in leachfield } \\
\text { - } \quad \text { Fill distribution box with inert material }\end{array}$ \\
\hline CAS 25-04-09 & $\begin{array}{l}\text { Engine Test } \\
\text { Stand }\end{array}$ & TPH & $\begin{array}{l}\text { Remove sediment from tank (if possible) } \\
\text { Remove tank or rinse and fill with inert } \\
\text { material }\end{array}$ \\
\hline CAS $25-04-10$ & $\begin{array}{l}\text { Intersection } \\
\text { of } C \text { and } G \\
\text { roads }\end{array}$ & None & Fill tank with an inert material \\
\hline CAS 25-04-11 & $\begin{array}{c}\text { Reactor } \\
\text { Control Point }\end{array}$ & $\mathrm{TPH}$ & $\begin{array}{l}\text { - } \\
\text { Relidify and remove tank contents } \\
\text { material } \\
\text { Remove TPH contaminated soil from } \\
\text { manhole, and remove manhole or rinse and } \\
\text { fill with inert material }\end{array}$ \\
\hline CAS 26-03-01 & $\begin{array}{l}\text { Port Gaston } \\
\text { Complex }\end{array}$ & Radionuclides & $\begin{array}{l}\text { Remove radionuclide contaminated soil } \\
\left(\sim 50 \mathrm{yd}^{3}\right)\end{array}$ \\
\hline CAS 26-04-01 & $\begin{array}{l}\text { Building } \\
2105\end{array}$ & Radionuclides & $\begin{array}{l}\text { Solidify and remove tank contents } \\
\text { Remove tank or rinse and fill with inert } \\
\text { material } \\
\text { Fill distribution box with inert material }\end{array}$ \\
\hline CAS 26-04-02 & $\begin{array}{l}\text { Building } \\
2103\end{array}$ & TPH & $\begin{array}{ll}\text { - } & \text { Remove sediment from tank (if possible) } \\
\text { Remove tank or rinse and fill with inert } \\
\text { material }\end{array}$ \\
\hline
\end{tabular}


TABLE 1 - GENERAL CLOSURE STRATEGY FOR CAU 271 (continued)

\begin{tabular}{|c|c|c|c|}
\hline CAS & Location & $\mathrm{COC}$ & Comments \\
\hline CAS 26-05-01 & $\begin{array}{l}\text { Building } \\
2201\end{array}$ & TPH, Radionuclides & $\begin{array}{l}\text { - } \\
\text { Remove manhole contents (if possible) } \\
\text { inert material } \\
\text { Remove radiologically contaminated soil } \\
\text { in leachfield }\left(\sim 24 \mathrm{yd}^{3}\right) \\
\text { Remove distribution box }\end{array}$ \\
\hline CAS 26-05-03 & $\begin{array}{l}\text { Building } \\
2203\end{array}$ & TPH & $\begin{array}{l}\text { Remove manhole and tank contents (if } \\
\text { possible) } \\
\text { - } \quad \text { Remove manhole and tank or rinse and fill } \\
\text { with inert material } \\
\text { Fill distribution box with inert material }\end{array}$ \\
\hline CAS 26-05-04 & $\begin{array}{c}\text { Building } \\
2201\end{array}$ & $\begin{array}{c}\text { TPH, Fecal Coliform } \\
\text { Bacteria }\end{array}$ & $\begin{array}{ll}\text { - } & \text { Neutralize bacteria } \\
\text { - } & \text { Solidify and remove tank contents } \\
\text { Remove tank or rinse and fill with inert } \\
\text { material } \\
\text { - } & \text { Fill distribution box with inert material }\end{array}$ \\
\hline CAS 26-05-05 & $\begin{array}{l}\text { Building } \\
2102\end{array}$ & TPH, Radionuclides & $\begin{array}{l}\text { - Solidify tank } 1 \text { contents and remove both } \\
\text { tank } 1 \text { and } 2 \text { contents } \\
\text { Remove tanks or rinse and fill with inert } \\
\text { material } \\
\text { Remove TPH contaminated soil }\left(\sim 26 \mathrm{yd}^{3}\right) \\
\text { in the leachfield } \\
\text { - }\end{array}$ \\
\hline CAS 27-05-02 & $\begin{array}{l}\text { Building } \\
5200\end{array}$ & $\begin{array}{l}\text { TPH, Radionuclides, } \\
\text { PCB (Polychlorinated } \\
\text { Biphenyls) }\end{array}$ & $\begin{array}{l}\text { - } \\
\text { distribution box contents } \\
\text { Remove tank and distribution box } \\
\text { Remove } P C B \text { contaminated soil } \\
\left(\sim 461 \mathrm{yd}^{3}\right) \text { in the leachfield }\end{array}$ \\
\hline
\end{tabular}

The following sections provide a brief description of each CAS. For a complete description, refer to the CADD (NNSA/NV, 2002).

\section{CAS 25-04-01, Septic System}

This system is located approximately 15.2 meters $(\mathrm{m})$ (50 feet [ft]) east of Jackass Flats Road, just south of the guard station at gate 500 in Area 25 of the NTS (Figure 2). The leachfield lies within a bermed area and is approximately $64.0 \mathrm{~m}$ ( $210 \mathrm{ft}$ ) long by $36.6 \mathrm{~m}$ (120 ft) wide. No distribution box is associated with the system. The interior of the tank measures $2.3 \mathrm{~m}(7.7 \mathrm{ft})$ long with a diameter of $0.9 \mathrm{~m}(3.1 \mathrm{ft})$. This system received sanitary effluent generated by activities from four trailers that provided offices for Wackenhut Services, Inc. and Nye County Sheriff's Department security personnel. Site characterization data reported in the CAU 271 CADD (NNSA/NV, 2002) indicate that the septic tank contents are impacted by total petroleum hydrocarbons (TPH). The leachfield was not impacted by contaminants of concern (COC) above action levels. 


\section{CAS 25-04-03, Septic System}

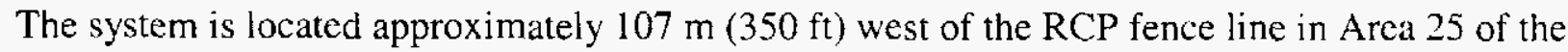
NTS (Figure 2). The leachfield is approximately $25.9 \mathrm{~m}(85 \mathrm{ft})$ long by $15.2 \mathrm{~m}(50 \mathrm{ft})$ wide. No distribution box is associated with this system. The interior of the septic tank measures $2.4 \mathrm{~m}$ $(7.8 \mathrm{ft})$ long by $1.1 \mathrm{~m}(3.5 \mathrm{ft})$ wide by $1.6 \mathrm{~m}(5.1 \mathrm{ft})$ deep. It received sanitary effluent from 18 trailers. Site characterization data reported in the CAU 271 CADD (NNSA/NV, 2002) indicate that the septic tank contains TPH and fecal coliform bacteria impacted waste. The leachfield was not impacted by COC above action levels.

\section{CAS 25-04-04, Septic System}

This system is located just south of the RCP fence line in Area 25 of the NTS (Figure 2). The leachfield is approximately $61.9 \mathrm{~m}(203 \mathrm{ft})$ long by $34.1 \mathrm{~m}(112 \mathrm{ft})$ wide. The system includes a distribution box measuring $1.8 \mathrm{~m}(6 \mathrm{ft})$ long by $7.3 \mathrm{~m}(4 \mathrm{ft})$ wide by $7.3 \mathrm{~m}(4 \mathrm{ft})$ deep. The

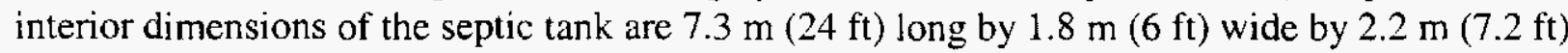
deep. This system received effluent from Building 3101 (Control Point), Building 3102 (Power House), Building 3103 (Los Alamos Scientific Laboratory Warehouse), Building 3106 (Storage Building), Building 3104 (Administration Building), Building 3105 (Former Medical/Cafeteria), Building 3107 (Service Station), and Building 3123 (Technical Services) (NNSA/NV, 2002). Site characterization data in the CAU 271 CADD (NNSA/NV, 2002) indicate that the septic tank contains TPH, pesticides, radionuclides, and fecal coliform bacteria impacted waste. Also, soil adjacent to the influent end of the septic tank is impacted with TPH. The leachfield and distribution box were not impacted by COC above action levels.

\section{CAS 25-04-08, Septic System}

This system is located approximately $30.5 \mathrm{~m}$ (100 ft) south of the Cane Springs Road at the entrance to the BREN Tower and east of the BREN Tower access road in Area 25 of the NTS (Figure 2). The leachfield is approximately $18.3 \mathrm{~m}(60 \mathrm{ft})$ long by $4.6 \mathrm{~m}(15 \mathrm{ft})$ wide. The system includes a distribution box measuring $1.3 \mathrm{~m}(4 \mathrm{ft})$ long by $1.3 \mathrm{~m}(4 \mathrm{ft})$ wide by $1.2 \mathrm{~m}$ (3.8 ft) deep. This system has a septic tank which measures about $2.4 \mathrm{~m}(7.9 \mathrm{ft})$ long by $1 \mathrm{~m}$ ( $3.1 \mathrm{ft})$ wide by $1.5 \mathrm{~m}(4.9 \mathrm{ft})$ deep. This system received effluent from BREN Tower support facilities. Site characterization data in the CAU 271 CADD (NNSA/NV, 2002) indicate that the leachfield contains a small amount of radiologically impacted soil, and the septic tank contains TPH impacted waste. The distribution box is not impacted by COC above action levels.

\section{CAS 25-04-09, Septic System}

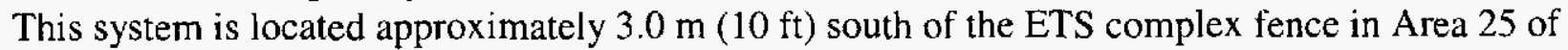
the NTS (Figure 2). The leachfield is approximately $36.6 \mathrm{~m}(120 \mathrm{ft})$ long by $18.3 \mathrm{~m}(60 \mathrm{ft})$ wide. The system includes a small distribution box and a septic tank. The interior of the tank measures about $4.7 \mathrm{~m}(15.5 \mathrm{ft})$ long by $1.3 \mathrm{~m}(4.3 \mathrm{ft})$ wide by $2.2 \mathrm{~m}(7.3 \mathrm{ft})$ deep. This system received effluent from Building 3340 (Test Cell Building), Building 3330 (Fill Station/Tank Farm and Forward Control area), Building 3320 (Utility Equipment Building/Substation Area), Building 3319 (Maintenance and Supply/Welding and Machine Shop), Building 3310 (Control Point Building), and as many as twenty-two trailers. Site characterization data in the CAU 27 I CADD (NNSA/NV, 2002) indicate that the septic tank contains TPH impacted waste. The distribution box and leachfield are not impacted by COC above action levels. 


\section{CAS 25-04-10, Septic System}

This system is located approximately $161 \mathrm{~m}(528 \mathrm{ft})$ south of the intersection of C and G Roads

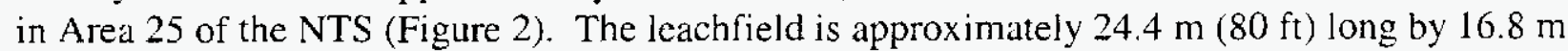
$(55 \mathrm{ft})$ wide. The system includes a distribution box measuring $1.3 \mathrm{~m}(4.3 \mathrm{ft})$ long by $0.7 \mathrm{~m}$ $(2.3 \mathrm{ft})$ wide by $0.9 \mathrm{~m}(3.1 \mathrm{ft})$ deep. The interior dimensions of the septic tank are $2.4 \mathrm{~m}(7.8 \mathrm{ft})$ in length with a diameter of $1.2 \mathrm{~m}(4 \mathrm{ft})$. This system received sanitary effluent from up to two Rad-Safe Trailers. Site characterization data in the CAU 271 CADD (NNSA/NV, 2002) indicate that the distribution box, leachfield, and septic tank are not impacted by $\mathrm{COC}$ above action levels.

\section{CAS 25-04-11, Septic System}

This system is located approximately $161.5 \mathrm{~m}(530 \mathrm{ft})$ south of the RCP Complex fence line in Area 25 of the NTS (Figure 2). The leachfield is approximately $61.0 \mathrm{~m}$ (200 ft) long by $41.1 \mathrm{~m}$ $(135 \mathrm{ft})$ wide. The system includes a distribution box measuring $1.2 \mathrm{~m}(4 \mathrm{ft})$ long by $1.2 \mathrm{~m}(4 \mathrm{ft})$ wide by $1.2 \mathrm{~m}(3.9 \mathrm{ft})$ deep. The interior of the tank measures about $1.8 \mathrm{~m}(5.5 \mathrm{ft})$ long, with a diameter of $1.8 \mathrm{~m}(5.8 \mathrm{ft})$. This system received effluent from Building 3127 (Cafeteria), Building 3129 (Technical Operations Building), and approximately 48 Los Alamos Scientific Laboratory trailers. Site characterization data in the CAU 271 CADD (NNSANNV, 2002) indicate that the septic tank contains TPH impacted waste. A small amount of TPH impacted soil is present in one system manhole. The distribution box and leachfield are not impacted by COC above action levels.

\section{CAS 26-03-01, Contaminated Water Reservoir}

This reservoir is located approximately $243.8 \mathrm{~m}(800 \mathrm{ft})$ south of the Port Gaston Complex in

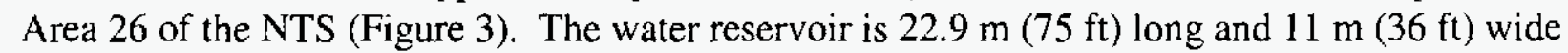
and is lined with 30 -mil thick black plastic. This system was constructed as a water reservoir for the Nuclear Weapons Accident Exercise training in 1981. Site characterization data in the CAU 271 CADD (NNSA/NV, 2002) indicate that the soil above the liner is radiologically impacted.

\section{CAS 26-04-01, Septic System}

This system is located approximately $61 \mathrm{~m}$ (200 ft) west of Building 2105 (Check Station) in Area 26 of the NTS (Figure 3). The leachfield is approximately $30 \mathrm{~m}(93 \mathrm{ft}$ ) long by $14.6 \mathrm{~m}$ (48 ft) wide. The system includes a distribution box measuring $1.6 \mathrm{~m}(5.1 \mathrm{ft})$ long by $1.5 \mathrm{~m}(5 \mathrm{ft})$ wide by $2.0 \mathrm{~m}(6.5 \mathrm{ft})$ deep. The interior of the systems septic tank measures about $2.2 \mathrm{~m}(7.2 \mathrm{ft})$ long by $1.7 \mathrm{~m}(5.5 \mathrm{ft})$ wide by $2.2 \mathrm{~m}(7.2 \mathrm{ft})$ deep. This system received effluent from Building 2105. Site characterization data in the CAU 271 CADD (NNSA/NV, 2002) indicate that the septic tank contains radiologically impacted waste. The distribution box and leachfield are not impacted by COC above action levels.

\section{CAS 26-04-02, Septic System}

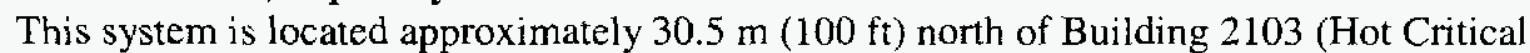
Facility). The leachfield is approximately $22.3 \mathrm{~m}(73 \mathrm{ft})$ long by $7.3 \mathrm{~m}(24 \mathrm{ft})$ wide. The system includes a distribution box measuring $1.2 \mathrm{~m}(4 \mathrm{ft})$ long by $1.2 \mathrm{~m}(4 \mathrm{ft})$ wide by $1.4 \mathrm{~m}(4.7 \mathrm{ft})$ deep. The systems septic tank interior measures about $1.8 \mathrm{~m}(6 \mathrm{ft})$ long by $0.9 \mathrm{~m}(3 \mathrm{ft})$ wide by $1.8 \mathrm{~m}(6 \mathrm{ft})$ deep. This system received effluent from Building 2103 . Site characterization data 
in the CAU 271 CADD (NNSA/NV, 2002) indicate that the septic tank contains TPH impacted waste, but the distribution box and leachfield are not impacted by $\mathrm{COC}$ above action levels.

\section{CAS 26-05-01, Radioactive Leachfield}

This system is located approximately $442 \mathrm{~m}(1,450 \mathrm{ft})$ southeast of Building 2201 (Disassembly

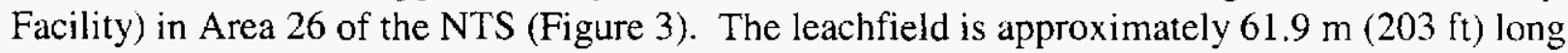
by $57.9 \mathrm{~m}(190 \mathrm{ft})$ wide. The system includes a distribution box measuring $1.2 \mathrm{~m}(4 \mathrm{ft})$ long by $1.2 \mathrm{~m}(4 \mathrm{ft})$ wide by $2.1 \mathrm{~m}(7 \mathrm{ft})$ deep, but does not include a septic tank. This system received effluent from Building 2201. Site characterization data in the CAU 271 CADD (NNSA/NV, 2002) indicate that the leachfield (near the distribution box) and one manhole contain radiologically impacted waste.

\section{CAS 26-05-03, System}

This system is located approximately $18.3 \mathrm{~m}(60 \mathrm{ft})$ southeast of Building 2203 (Test Bunker) in Area 26 of the NTS (Figure 3). The leachfield is approximately $28.3 \mathrm{~m}(93 \mathrm{ft}$ ) long by $14.6 \mathrm{~m}$ $(48 \mathrm{ft})$ wide. The system includes a distribution box measuring $1.2 \mathrm{~m} \mathrm{(4ft)}$ long by $1.2 \mathrm{~m}(4 \mathrm{ft})$ wide by $1.2 \mathrm{~m}(4 \mathrm{ft})$ deep. The interior of the systems septic tank measures about $3.0 \mathrm{~m}(10 \mathrm{ft})$ long by $1.5 \mathrm{~m}(5 \mathrm{ft})$ wide by $2.1 \mathrm{~m}(7 \mathrm{ft})$ deep. This system received effluent from Building 2203. Site characterization data in the CAU 271 CADD (NNSA/NV, 2002) indicate that the septic tank and manhole contain a small amount of TPH impacted sediment, but the distribution box and leachfield are not impacted by COC above action levels.

\section{CAS 26-05-04, Septic System}

This system is located approximately $76.2 \mathrm{~m}$ (250 ft) south of Building 2201 (Disassembly Facility) in Area 26 of the NTS (Figure 3). The leachfield is approximately $76.2 \mathrm{~m}(83 \mathrm{ft}$ ) long by $19.5 \mathrm{~m}(64 \mathrm{ft})$ wide. The system includes a distribution box measuring $1.2 \mathrm{~m}(4 \mathrm{ft})$ long by $1.2 \mathrm{~m}(4 \mathrm{ft})$ wide by $1.8 \mathrm{~m}(6 \mathrm{ft})$ deep. This system also has a septic tank which measures about $2.0 \mathrm{~m}(6.5 \mathrm{ft})$ long by $1.8 \mathrm{~m}(6 \mathrm{ft})$ wide by $2.0 \mathrm{~m}(6.8 \mathrm{ft})$ deep. This system received sanitary effluent from Building 2201. Site characterization data in the CAU 271 CADD (NNSA/NV, 2002) indicate that the septic tank contains TPH and fecal coliform bacteria impacted waste. The distribution box and leachfield are not impacted by COC above action levels.

\section{CAS 26-05-05, Septic System}

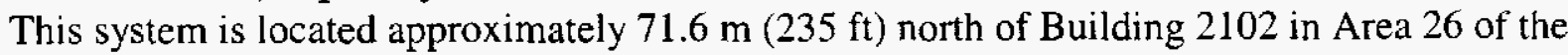
NTS (Figure 3). It is comprised of two leachfields, two distribution boxes, and two septic tanks.

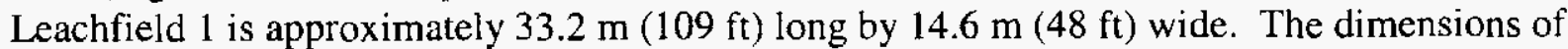
leachfield 2 were not given in the CAU 271 CADD (NNSA/NV, 2002). Distribution box 1 measures $1.0 \mathrm{~m}(3.3 \mathrm{ft})$ long by $0.9 \mathrm{~m}(3 \mathrm{ft})$ wide by $1.5 \mathrm{~m}(5 \mathrm{ft})$ deep. Distribution box 2

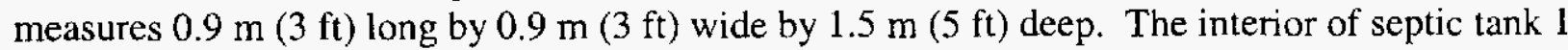
measures about $1.6 \mathrm{~m}(5.3 \mathrm{ft})$ long by $1.6 \mathrm{~m}(5.3 \mathrm{ft})$ wide by $1.6 \mathrm{~m}(5.3 \mathrm{ft})$ deep. The interior of septic tank 2 measures about $7.3 \mathrm{~m}(24 \mathrm{ft})$ long by $1.2 \mathrm{~m}(3.8 \mathrm{ft})$ wide by $1.5 \mathrm{~m}(5 \mathrm{ft})$ deep. This system received effluent from Building 2201, Building 2102, and Building 2107. Site characterization data in the CAU 271 CADD (NNSA/NV, 2002) indicate that septic tank 1 contains TPH impacted waste and septic tank 2 contains TPH and radiologically impacted waste. 
Leachfield 2 contains TPH impacted soil. Both distribution boxes 1 and 2 and leachficld 1 are not impacted by COC above action levels.

\section{CAS 27-05-02, Septic System}

This system is located southwest of Building 5200 (Mechanical Technician Shop), and Building 5210 (Cafeteria) in Area 27 of the NTS (Figure 4). The leachfield is approximately $24.4 \mathrm{~m}$

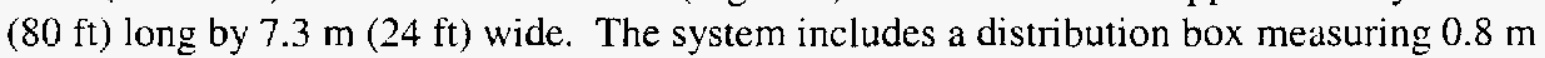
(2.7 ft) long, with a diameter of $0.7 \mathrm{~m}(2.3 \mathrm{ft})$. This system is also equipped with a septic tank. The interior dimensions of the septic tank are $2.7 \mathrm{~m}(9 \mathrm{ft})$ in length, with a diameter of $1.7 \mathrm{~m}$ $(5.5 \mathrm{ft})$. This system received effluent from Building 5200 and Building 5210. Site characterization data in the CAU 271 CADD (NNSA/NV, 2002) indicate that the septic tank and distribution box contain TPH, Polychlorinated Biphenyls (PCB), and radiologically impacted waste. The leachfield contains PCB impacted soil.

\subsection{PURPOSE}

The purpose of this CAP is to provide the specific methods for implementing the recommended corrective action alternatives as specified in the CADD (NNSA/NV, 2002). Detailed information on the site history and results of characterization activities are located in the Corrective Action Investigation Plan (CAIP) (NNSA/NV, 2001) and CADD (NNSA/NV, 2002).

The CAIP (NNSA/NV, 2001) describes the site history, outlines a site characterization plan, and proposes Preliminary Action Levels to evaluate the need for possible site corrective actions. Site characterization activities were performed in 2001 and 2002. Site characterization results were reported in Appendix A of the CADD (NNSA/NV, 2002). The CADD specified that Corrective Action Alternative 2 - Clean Closure, shall be implemented at all of the CASs except CAS 25-04-10, Septic System. For CAS 25-04-10, the CADD (NNSA/NV, 2002) reported that the septic tank is empty, the distribution box is filled with sediment to the ground surface, and that no COC were found. This CAS will be closed by Corrective Action Alternative 1 - No Further Action, but as a best management practice the septic tank will be filled with an inert material.

\subsection{SCOPE}

Specific details of the corrective actions to be performed at each CAS are presented in Section 2.0 - Detailed Statement of Work.

\subsection{CORRECTIVE ACTION PLAN CONTENTS}

This CAP is divided into the following sections:

- Section 1.0 - Introduction

- Section 2.0 - Detailed Statement of Work 
- Section 3.0 - Schedule

- Section 4.0 - Post-Closure Monitoring Plan

- Section 5.0 - References

The appendices of this document are as follows:

- Appendix A.l: Engineering Specifications and Drawings

- Appendix A.2: Sampling and Analysis Plan

- Appendix A.3: Project Organization

- Appendix B: Nevada Division of Environmental Protection Document Review Sheet

- Distribution List

This report was primarily developed using information and guidance from the following documents:

- Federal Facility Agreement and Consent Order, 1996 as amended. Agreed to by the State of Nevada, the U.S. Department of Energy, and the U.S. Department of Defense.

- U.S. Department of Energy, Nevada Operations Office, 2001. Corrective Action Investigation Plan for Corrective Action Unit 271: AREAS 25, 26, AND 27 SEPTIC SYSTEMS, DOE/NV--704, Las Vegas, NV.

- U.S. Department of Energy, Nevada Operations Office, 2002. Corrective Action Decision Document for Corrective Action Unit 271: AREAS 25, 26, AND 27 SEPTIC SYSTEMS, Nevada Test Site, Nevada, DOE/NV--838-REV 0, Las Vegas, NV. 


\subsection{DETAILED STATEMENT OF WORK}

\subsection{CORRECTIVE ACTIONS}

The objectives of the corrective action alternatives specified in the CADD (NNSA/NV, 2002) are to prevent or mitigate adverse environmental impacts due to exposure and migration of surface and subsurface waste. All of the CASs in CAU 271 will be closed by Corrective Action Alternative 2 - Clean Closure except CAS 25-04-10, Septic System. For CAS 25-04-10, the CADD (NNSA/NV, 2002) reported that the septic tank is empty, the distribution box is filled with sediment to the ground surface, and that no $\mathrm{COC}$ were found. This CAS will be closed by Corrective Action Alternative 1 - No Further Action, but as a best management practice the septic tank will be filled with an inert material.

\subsubsection{Clean Closure of Septic Tanks}

This section provides a general methodology for clean closing CAU 271 septic tanks. CAS specific closure methodology is presented in subsequent sections. The following 12 CASs contain septic tanks that will be clean closed

- CAS 25-04-01, Septic System

- CAS 25-04-03, Septic System

- CAS 25-04-04, Septic System

- CAS 25-04-08, Septic System

- CAS 25-04-09, Septic System

- CAS 25-04-11, Septic System

- CAS 26-04-01, Septic System

- CAS 26-04-02, Septic System

- CAS 26-05-03, Septic System

- CAS 26-05-04, Septic System

- CAS 26-05-05, Septic System

- CAS 27-05-02, Leachfield

The top of the septic tanks will be exposed and removed as necessary. An appropriate amount of bleach, chlorine, or equivalent bacteria neutralization agent will be added to any tank that contains fecal coliform bacteria. The tank contents will be solidified in the septic tank by adding clean fill and mixing with the appropriate equipment. Waste characterization samples will then be collected and submitted for analysis as stated in Sections 2.1.5 to 2.1.19. Upon receipt of the sample results, the waste will be removed using the appropriate heavy equipment. Waste containing only TPH will either be placed in trucks for transportation to the Area 6 hydrocarbon landfill or placed on and covered with plastic near the septic tank. All other waste streams such as Mixed Waste (MW), Low Level Waste (LLW), and Hazardous Waste (HW) will be placed in appropriate containers and transported to a Waste Accumulation Area (WAA). If there is not enough free space to solidify the contents of the tank, a portion of the liquid in the tank will be 
pumped into a lined solidification basin. Once there is enough free space in the tank, the remainder of the tank contents will be solidified with clean fill. The tank will then be removed from the ground by the appropriate equipment and disposed in an proper facility.

After the tank is removed, a number of verification soil samples will be collected from the excavation and submitted for laboratory analysis for all COC found at that CAS. A minimum of five verification samples (one from each of the side walls and bottom of the excavation) will be collected and analyzed. If verification sample results indicate any action level is exceeded, additional soil will be removed.

Once verification sample results indicate that all the samples are below the applicable action level, the excavation will be backfilled with clean fill using a front-end loader or equivalent equipment, and graded to its original contours. If necessary, water will be sprayed onto the fill material during the backfill activity to reduce dust and promote compaction.

If it is not feasible to remove the tank from the ground, the site will be clean closed by removing, analyzing, and disposing the waste as stated above. After removal of the tank contents, the tank interior will be pressure washed/steam cleaned and rinsed to remove any removable scale or residual material. The initial rinse water will be pumped from the septic tank, solidified in a lined solidification basin, and disposed in an appropriate facility. The final rinse water will be left in the tank. A sample will be collected from within the septic tank and analyzed for the COC found in the septic tank to verify clean closure of the tank. If analytical results of the final rinse water indicate residual contamination in excess of the COC action levels, additional cleaning and rinsing will be completed until acceptable analytical results are obtained. Upon receipt of analytical results showing the rinsate is below the COC action levels, the rinsate remaining in the septic tank will be solidified in place using clean fill and filled with an inert material. This will effectively seal the effluent ends of the tank.

Sections 2.1.5 to 2.1.19 describe the COC found at each CAS, any site specific modifications to the above plan, and the type of additional waste characterization analysis, if needed, that will be performed.

\subsubsection{Clean Closure of Impacted Soil}

The following six CASs contain contaminated soil and will be clean closed as described below:

- CAS 25-04-04, Septic System

- CAS 25-04-08, Septic System

- CAS 26-05-01, Radioactive Leachfield

- CAS 26-03-01, Contaminated Water Reservoir

- CAS 26-05-05, Septic System

- CAS 27-05-02, Leachfield 
The estimated volume of impacted soil, as presented in the CADD (NNSA/NV, 2002 ), will be removed. Waste containing only TPH will either be placed in trucks for transportation to the Area 6 hydrocarbon landfill or placed on and covered with plastic adjacent to the excavation. All other waste streams (MW, HW, or LLW) will be packaged in appropriate containers and transported to a WAA. After the estimated volume of soil has been removed, a number of verification soil samples will be collected from the excavation and submitted for laboratory analysis for all COC found at that CAS. A minimum of five verification samples (one from each of the side walls and bottom of the excavation) will be collected and analyzed. If verification sample results indicate any action level is exceeded, additional soil will be removed.

Once verification sample results indicate that all samples are below the applicable action level, the excavation will be backfilled with clean fill using a front-end loader or equivalent equipment, and graded to its original contours. If necessary, water will be sprayed onto the fill material during the backfill activity to reduce dust and promote compaction. In order to determine the proper disposal of the soil, waste characterization samples will be collected and analyzed. Upon receipt of analytical results, the waste will be disposed in an appropriate disposal facility.

Sections 2.1.5 to 2.1.19 describe the COC found at each CAS, any site specific modifications to the above plan, and the type of additional waste characterization analysis, if needed, that will be performed.

\subsubsection{Clean Closure of Contaminated Manholes}

The following three CASs contain contaminated manholes and will be clean closed as described below.

- CAS 25-04-11, Septic System

- CAS 26-05-01, Radioactive Leachfield

- CAS 26-05-03, Septic System

If possible, the impacted material will be removed from the pre-cast manhole. The manhole will be taken out of the ground with the proper equipment and disposed in the appropriate facility. Waste containing only TPH will either be placed in trucks for transportation to the Area 6 hydrocarbon landfill or placed on and covered with plastic near the manhole. All other waste streams, such as MW, HW, and LLW, will be placed in appropriate containers and transported to a WAA. After the manhole is removed, a number of verification soil samples will be collected from the excavation and submitted for laboratory analysis for all COC found at that CAS. A minimum of five verification samples (one from each of the side walls and bottom of the excavation) will be collected and analyzed. If verification sample results indicate any action level is exceeded, additional soil will be removed.

Once verification sample results indicate all of the samples are below the applicable action level, the excavation will be backfilled with clean fill using a front-end loader or equivalent equipment, and graded to its original contours. If necessary, water will be sprayed onto the fill material 
during the backfill activity to reduce dust and promote compaction. In order to determine the proper disposal of the manhole and its contents, waste characterization samples will be collected and analyzed. Upon receipt of analytical results, the waste will be disposed in an proper disposal facility.

If it is not is not practical to remove the manhole, the manhole interior will be pressure washed/steam cleaned and rinsed to remove any removable scale or residual material. The initial rinse water will be pumped from the septic tank, solidified, and disposed in an appropriate facility. A sample of the final rinse water will be collected from within the manhole and analyzed for $\mathrm{COC}$ found to verify clean closure. If analytical results of the final rinse water indicate residual contamination in excess of the COC action levels, additional cleaning and rinsing will be completed until acceptable analytical results are obtained. Upon receipt of analytical results, the waste will be disposed in an appropriate disposal facility. The rinsate remaining in the manhole will be solidified in place using clean fill and the manhole will be filled with an inert material. This will effectively seal the effluent ends of the manhole.

Sections 2.1.5 to 2.1.19 describe the COC found at each CAS, any site specific modifications to the above plan, and the type of additional waste characterization analysis, if needed, that will be performed.

\subsubsection{Clean Closure of Distribution Boxes}

All distribution boxes identified in the CADD (NNSA/NV, 2002) to be clean closed, except at CAS 26-05-01 and CAS 27-05-02, will be clean closed by filling the distribution box with an inert material. This will effectively seal the effluent ends of the distribution box. The distribution box at CAS 26-05-01 will be clean closed as stated in Section 2.1.15, and the distribution box at CAS 27-05-02 will be clean closed as stated in Section 2.1.19. These sections describe the COC found, site specific modifications to the above plan, and waste characterization activities that will be performed.

\subsubsection{CAS 25-04-01, Septic System}

The CADD (NNSA/NV, 2002) reported that the septic tank contains approximately 614 liters (L) (135 gallons [gal]) of hydrocarbon-impacted liquid and sludge that exceeds the State of Nevada TPH action level of 100 milligram per kilogram $(\mathrm{mg} / \mathrm{kg})$ as stated in the Nevada Administrative Code (NAC) 445A.2272 for action levels for petroleum hydrocarbons (NAC, 2002).

This septic tank shall be clean closed as stated in Section 2.1.1. A waste characterization sample will be collected and analyzed for gamma emitting radionuclides by either an In-situ Object Counting System (ISOCS) or laboratory analysis. Upon receipt of analytical results, the waste will be disposed in an appropriate on-site disposal facility. 


\subsubsection{CAS 25-04-03, Septic System}

The CADD (NNSA/NV, 2002) reported that the septic tank contains approximately $1,681 \mathrm{~L}$ (444 gal) of hydrocarbon-impacted liquid and sludge that exceeds the State of Nevada TPH action level of $100 \mathrm{mg} / \mathrm{kg}$. Fecal coliform bacteria was also found in the tank.

This CASs septic tank shall be clean closed as stated in Section 2.1.1. A waste characterization sample will be collected and analyzed for gamma emitting radionuclides by either ISOCS or laboratory analysis. Upon receipt of analytical results, the waste will be disposed in an appropriate on-site disposal facility.

\subsubsection{CAS 25-04-04, Septic System}

The CADD (NNSA/NV, 2002) reported that the influent side of the septic tank contains approximately $15,732 \mathrm{~L}(4,156 \mathrm{gal})$ of hydrocarbon-impacted liquid and sludge that exceeds the State of Nevada TPH action level of $100 \mathrm{mg} / \mathrm{kg}$. The effluent chamber contains approximately $2,302 \mathrm{~L}$ (608 gal) of liquid and sludge that exceeds the applicable action level for Uranium 238, Chlordane, and TPH. Both sides of the tank contain fecal coliform bacteria. Also the CADD (NNSA/NV, 2002) estimates that 321 cubic meters $\left(\mathrm{m}^{3}\right)\left(420\right.$ cubic yards [yd $\left.\mathrm{d}^{3}\right]$ ) of hydrocarbon impacted soil, adjacent to the influent end of the septic tank, exceeds the State of Nevada TPH action level of $100 \mathrm{mg} / \mathrm{kg}$ (Figure 5).

Based on the CADD (NNSA/NV, 2002) site characterization data, additional samples need to be collected and analyzed from the septic tank before clean up activities can commence. This will be done by first neutralizing the fecal coliform bacteria using an appropriate amount of bleach, chlorine, or equivalent bacteria neutralization agent. The tank will then be mixed by using the appropriate equipment. Two samples will be taken from each chamber and analyzed for TPH (full scan), Toxicity Characterization Leaching Procedure (TCLP) Pesticides, gamma emitting radionuclides, and Isotopic Uranium. Depending on the analytical results, the contents of the chambers may be solidified, removed, and disposed separately in order to reduce the possibility of mixing the different waste streams.

The septic tank and contaminated soil near the tank shall be clean closed as stated in Sections 2.1.1 and 2.1.2. Waste characterization sample(s) will be collected from the septic tank and submitted for laboratory analysis for TPH (full scan) TCLP Pesticides, gamma emitting radionuclides, and Isotopic Uranium. A waste characterization sample collected from the TPH impacted soil will be analyzed for gamma emitting radionuclides by either ISOCS or laboratory analysis. Upon receipt of analytical results, the waste will be disposed in a proper disposal facility.

The distribution box will be closed as stated in Section 2.1.4.

\subsubsection{CAS 25-04-08, Septic System}

The CADD (NNSA/NV, 2002) reported that the influent side of the septic tank contains approximately $1,707 \mathrm{~L}$ (451 gal) of hydrocarbon-impacted liquid and sludge that exceeds the 


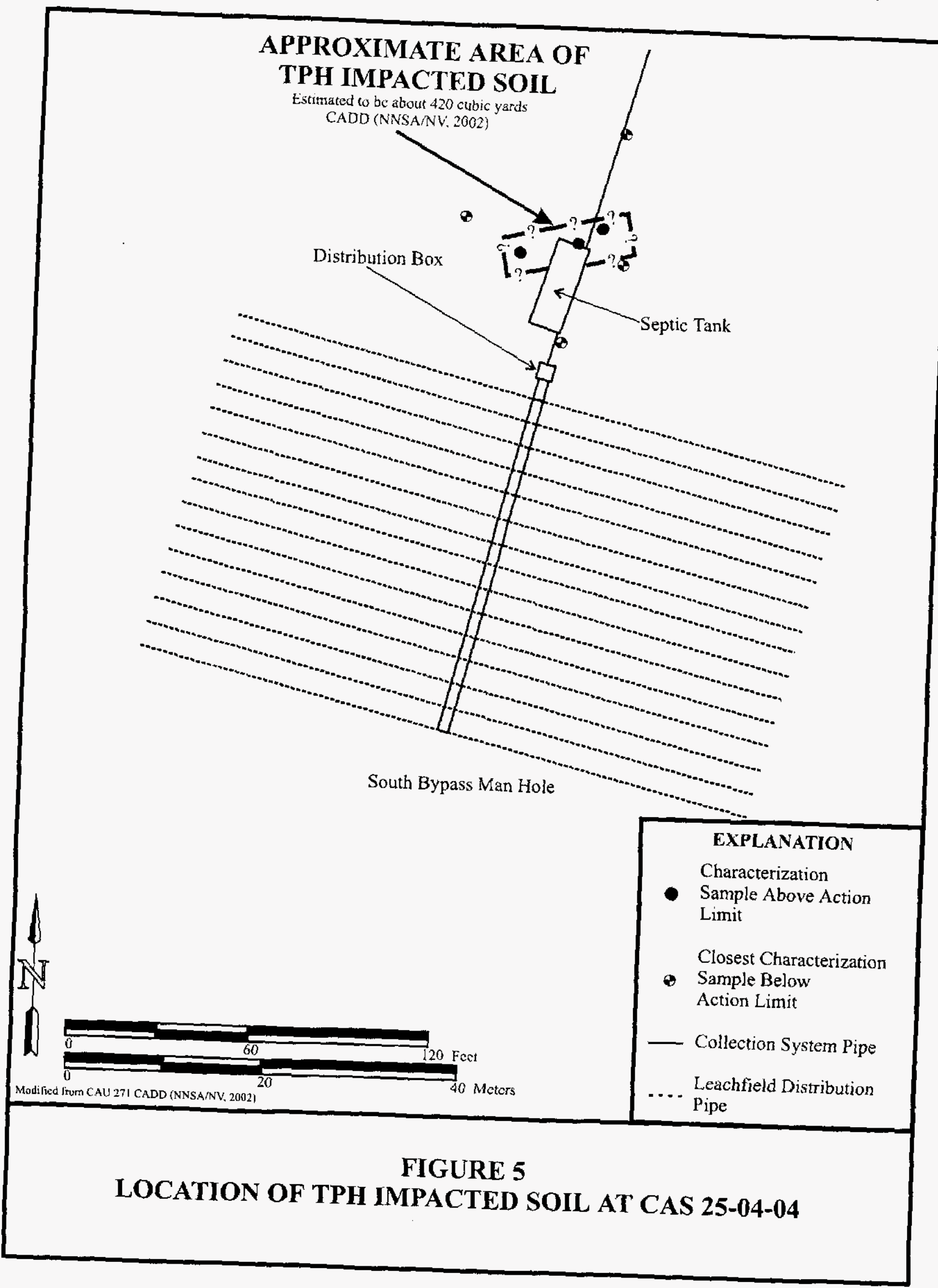


State of Nevada TPH action level of $100 \mathrm{mg} / \mathrm{kg}$. The effluent chamber contains approximately $659 \mathrm{~L}$ (174 gal) of hydrocarbon-impacted liquid and sludge. Also the CADD (NNSA/NV, 2002) reported that an estimated $2.3 \mathrm{~m}^{3}\left(3 \mathrm{yd}^{3}\right)$ of soil in the southern portion of the leachfield is contaminated with Plutonium (Figure 6).

The septic tank and contaminated soil near the tank shall be clean closed as stated in sections 2.1.1 and 2.1.2. A waste characterization sample collected from the septic tank will be submitted for laboratory analysis of gamma emitting radionuclides by either ISOCS or laboratory analysis. Upon receipt of analytical results the waste will be disposed in a proper disposal facility. If any leachfield piping is encountered during excavation activities, a characterization sample will be collected from the material in the piping. This sample will be analyzed for volatile organic compounds (VOC), semi volatile organic compounds (SVOC), TPH (full scan), Resource Conservation and Recovery Act (RCRA) metals, PCB, gamma emitting radionuclides, Isotopic Uranium, and Isotopic Plutonium.

\subsubsection{CAS 25-04-09, Septic System}

The CADD (NNSANV, 2002) reported that the influent and effluent side of the septic tank combined contain approximately $416 \mathrm{~L}(110 \mathrm{gal})$ of hydrocarbon-impacted sediment that exceeds the State of Nevada TPH action level of $100 \mathrm{mg} / \mathrm{kg}$.

This CASs septic tank shall be clean closed as stated in Section 2.1.1. A waste characterization sample will be collected and analyzed for gamma emitting radionuclides by either ISOCS or laboratory analysis. Upon receipt of analytical results, the waste will be disposed in an appropriate on-site disposal facility.

\subsubsection{CAS 25-04-10, Septic System}

The CADD (NNSANN , 2002) reported that the septic tank is empty, the distribution box is filled with sediment to the ground surface, and no COC were present above action levels. As a best management practice the septic tank will be filled with an inert material.

\subsubsection{CAS 25-04-11, Septic System}

The CADD (NNSA/NV, 2002) reported that the influent side of the septic tank contains approximately $1,567 \mathrm{~L}$ (414 gal) hydrocarbon-impacted liquid and sludge that exceeds the State of Nevada TPH action level of $100 \mathrm{mg} / \mathrm{kg}$. The effluent chamber contains approximately $1,083 \mathrm{~L}$ ( 286 gal) hydrocarbon-impacted liquid and sludge. Also a small amount of TPH contaminated sediment is present in a manhole.

The septic tank and manhole shall be clean closed as Stated in sections 2.1.1 and 2.1.3. A waste characterization sample will be collected and analyzed from the tank and manhole for gamma emitting radionuclides by either ISOCS or laboratory analysis. Upon receipt of analytical results, the waste will be disposed in an appropriate on-site disposal facility. 


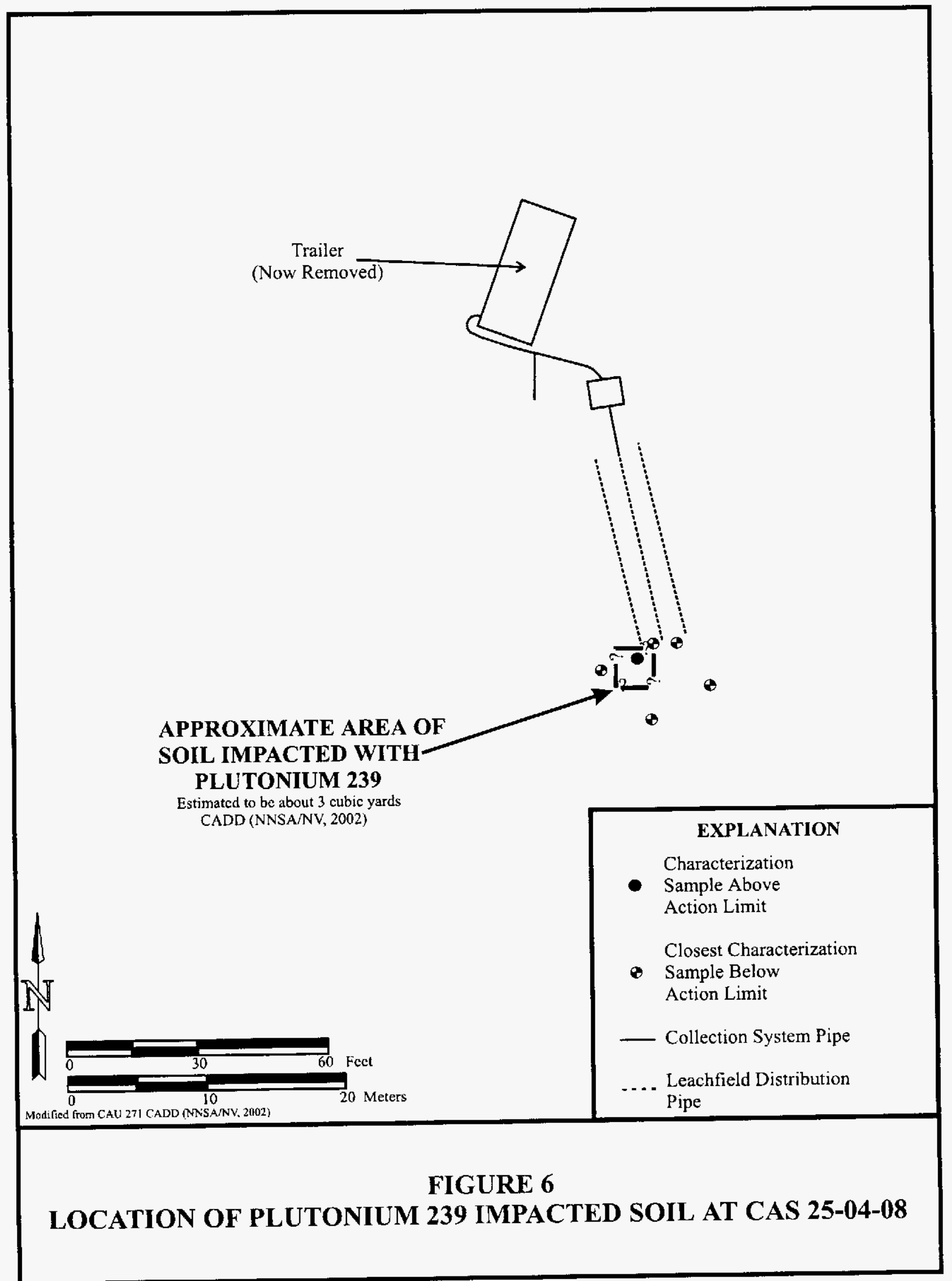




\subsubsection{CAS 26-03-01, Contaminated Water Reservoir}

The CADD (NNSA/NV, 2002) reported that the first $0.15 \mathrm{~m}(0.5 \mathrm{ft})$ of soil in this reservoir is impacted with Lead 214, Thorium 227, and Actinium 227 that exceeds the applicable action level.

The plastic liner and approximately $38 \mathrm{~m}^{3}\left(50 \mathrm{yd}^{3}\right)$ of impacted soil shall be removed and five verification samples will be collected from the base of the shallow excavation.

\subsubsection{CAS 26-04-01, Septic System}

The CADD (NNSA/NV, 2002) reported that the septic tank contains approximately $3,907 \mathrm{~L}$ (1,032 gal) of liquid and sludge that exceeded the applicable clean-up criteria for Cesium 137 and Plutonium 239.

The septic tank shall be clean closed as stated in Section 2.1.1, and a waste characterization sample will be collected and submitted for laboratory analysis of gamma emitting radionuclides and Isotopic Plutonium. Upon receipt of analytical results, the waste will be packaged in approved containers and disposed in an appropriate on-site disposal facility.

The distribution box will be closed as stated in Section 2.1.4.

\subsubsection{CAS 26-04-02, Septic System}

The CADD (NNSA/NV, 2002) reported that the septic tank contains approximately $129 \mathrm{~L}$ (34 gal) of hydrocarbon-impacted sediment that exceeded the State of Nevada TPH action level of $100 \mathrm{mg} / \mathrm{kg}$.

The septic tank shall be clean closed as stated in Section 2.1.1, and a waste characterization sample will be collected and analyzed for gamma emitting radionuclides by either ISOCS or laboratory analysis. Upon receipt of the data, the waste will be disposed in an appropriate facility.

The distribution box will be closed as stated in Section 2.1.4.

\subsubsection{CAS 26-05-01, Radioactive Leachfield}

The CADD (NNSA/NV, 2002) reported that manhole 1 contains approximately $38 \mathrm{~L}$ (10 gal) of sediment that exceeds the applicable action level for Uranium 234, Uranium 235, Plutonium 239, Cesium 137, and TPH. Also the CADD (NNSA/NV, 2002) reported that an estimated $24 \mathrm{~m}^{3}$ $\left(18 \mathrm{yd}^{3}\right)$ of soil in the southern portion of the leachfield is contaminated with Plutonium 239 and Uranium 234 and 235 (Figure 7).

The leachfield and manhole will be clean closed as stated in section 2.1.2 and 2.1.3. A waste characterization sample will be collected from the manhole and analyzed for TPH, gamma emitting radionuclides, Isotopic Plutonium, and Isotopic Uranium. Also a waste characterization 


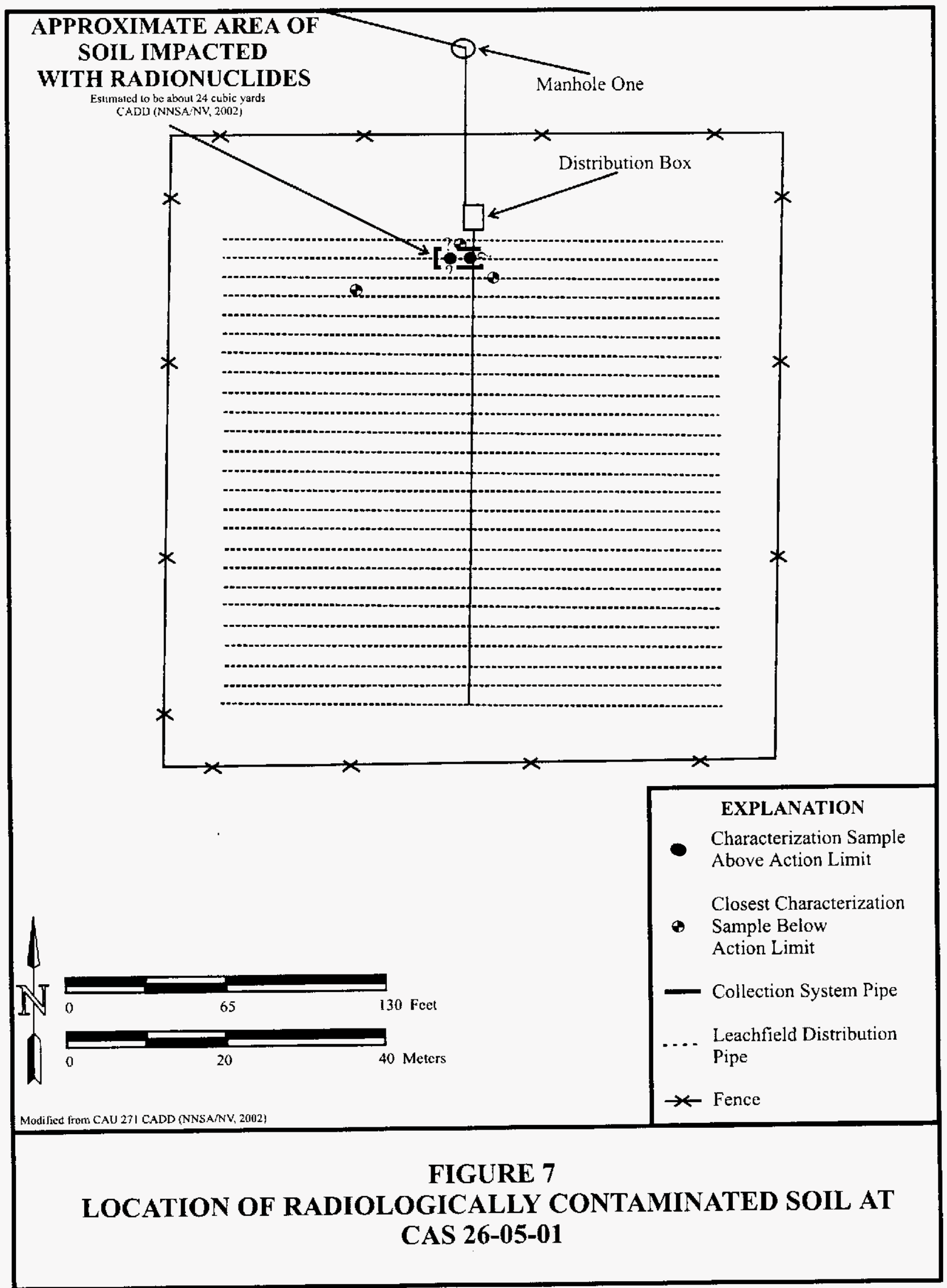


sample will be collected from the leachfield and analyzed for gamma emitting radionuclides, Isotopic Plutonium, and Isotopic Uranium. Upon receipt of the data, the waste will be disposed in an appropriate facility.

The distribution box will be clean closed as stated in Section 2.1.1.

\subsubsection{CAS 26-05-03, Septic System}

The CADD (NNSA/NV, 2002) reported that the septic tank and manhole each contain about $1.9 \mathrm{~L}(0.5 \mathrm{gal})$ of hydrocarbon-impacted sediment that exceeded the State of Nevada TPH action level of $100 \mathrm{mg} / \mathrm{kg}$.

The septic tank and manhole shall be clean closed as stated in Sections 2.1.1 and 2.1.3. A waste characterization sample will be collected and analyzed for gamma emitting radionuclides by either ISOCS or laboratory analysis. Upon receipt of analytical results, the waste will be disposed in an appropriate on-site disposal facility.

The distribution box will be closed as stated in Section 2.1.4.

\subsubsection{CAS 26-05-04, Septic System}

The CADD (NNSA/NV, 2002) reported that the influent side of the septic tank contains approximately 14,203 L (3752 gal) hydrocarbon-impacted liquid and sludge that exceeds the State of Nevada TPH action level of $100 \mathrm{mg} / \mathrm{kg}$. The effluent chamber contains approximately $182 \mathrm{~L}$ (48 gal) of hydrocarbon-impacted liquid and sludge. Fecal coliform bacteria was detected in both chambers. This CAS shall be clean closed by the following.

This CASs septic tank shall be clean closed as stated in Section 2.1.1. A waste characterization sample will be collected and analyzed for gamma emitting radionuclides by either ISOCS or laboratory analysis. Upon receipt of analytical results, the waste will be disposed in an appropriate on-site disposal facility.

The distribution box will be closed as stated in Section 2.1.4.

\subsubsection{CAS 26-05-05, Septic System}

The CADD (NNSA/NV, 2002) reported that septic tank 1 contains approximately $3,490 \mathrm{~L}$ (922 gal) of hydrocarbon-impacted liquid and sludge that exceeded the State of Nevada TPH action level of $100 \mathrm{mg} / \mathrm{kg}$. Septic tank 2 contains approximately $216 \mathrm{~L}$ (57 gal) of sediment that exceeded the applicable action level for Uranium 234, Uranium 235, Plutonium 239, and TPH. Also the CADD (NNSA/NV, 2002) estimates that $20 \mathrm{~m}^{3}\left(26 \mathrm{yd}^{3}\right)$ of soil in the leachfield exceeded the State of Nevada TPH action level of $100 \mathrm{mg} / \mathrm{kg}$ (Figure 8 ). This CAS shall be clean closed by the following. 


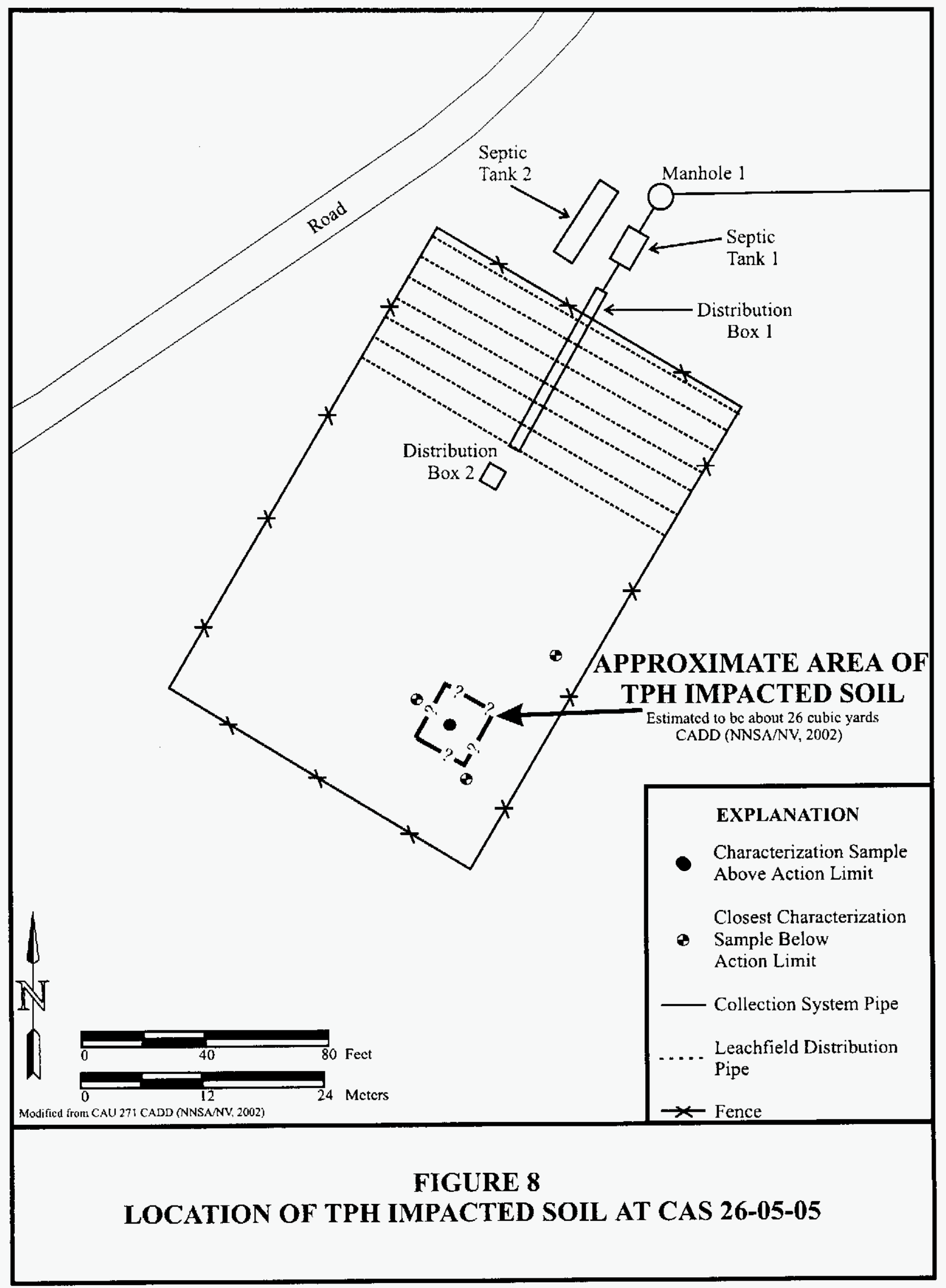


Septic tank 1 shall be clean closed as stated in Section 2.1.1, and a waste characterization sample will be collected and submitted for laboratory analysis of gamma emitting radionuclides by either ISOCS or laboratory analysis. Septic tank 2 shall be clean closed as stated in Section 2.1.1, and a waste characterization sample will be collected and submitted for laboratory analysis for TPH. Isotopic Uranium, Isotopic Plutonium, and gamma emitting radionuclides. Also, the TPH impacted soil in the leachfield will be clean closed by excavation and removal as stated in Section 2.1.2. A waste characterization sample will be collected and submitted for laboratory analysis of gamma emitting radionuclides by either ISOCS or laboratory analysis. Upon receipt of analytical results, the waste will be disposed in a appropriate on-site disposal facility.

If any leachfield piping is encountered during excavation activities, a characterization sample will be collected from the material in the piping. This sample will be analyzed for VOC, SVOC, TPH, RCRA metals, PCB, gamma emitting radionuclides, Isotopic Uranium, and Isotopic Plutonium.

Both distribution boxes will be closed as stated in Section 2.1.4.

\subsubsection{CAS 27-05-02, Septic System}

The CADD (NNSA/NV, 2002) reported that the influent side of the septic tank contains approximately $587 \mathrm{~L}$ (155 gal) of sludge that exceeds the applicable clean-up criteria for Uranium 234, Uranium 235, PCB, and hydrocarbons, and approximately $2,578 \mathrm{~L}$ (681 gal) of liquid that exceeds the applicable clean-up criteria for gross alpha and beta emitters. The effluent chamber contains approximately $905 \mathrm{~L} \mathrm{(239} \mathrm{gal})$ of liquid that exceeds the applicable clean-up criteria for gross alpha and beta emitters. The distribution box contains approximately $19 \mathrm{~L}$ ( 5 gal) of sludge that exceeded the applicable clean-up criteria for Uranium 234, Uranium 235 , Uranium 238, PCB, and TPH. The leachfield and surrounding area contain approximately $1,376 \mathrm{~m}^{3}\left(1,800 \mathrm{yd}^{3}\right)$ of soil that exceeds the applicable clean-up criteria for PCB CADD (NNSA/NV, 2002). However, per the approved CADD (NNSA/NV, 2002), only $352 \mathrm{~m}^{3}$ $\left(461 \mathrm{yd}^{3}\right)$ of soil is within the defined CAS boundary. Only the contaminated soil that is within the leachfield fence will be removed during CAU 271 closure activities (Figure 9). This CAS shall be clean closed by the following method.

The septic tank and distribution box will be clean closed as stated in Section 2.1.1 except for the following changes. In order to minimize the possibility of mixing the non PCB-impacted radiological waste (liquid) in the effluent chamber of the septic tank with the $\mathrm{PCB} /$ radiological/TPH (sludge) in the influent chamber and distribution box during extraction, the two waste streams will be pumped separately into different lined evaporation basins. If the materials in both chambers are mixed on removal it will be managed as a PCB/radiological/TPH waste. Any excess liquid in the evaporation basin will be absorbed by an inert material. Waste characterization sample(s) will be collected and analyzed for TPH, PCB, Isotopic Uranium, and gamma emitting radionuclides. Upon receipt of the characterization sample(s), the waste will be packaged in appropriate containers and disposed at an approved facility. The PCB impacted 


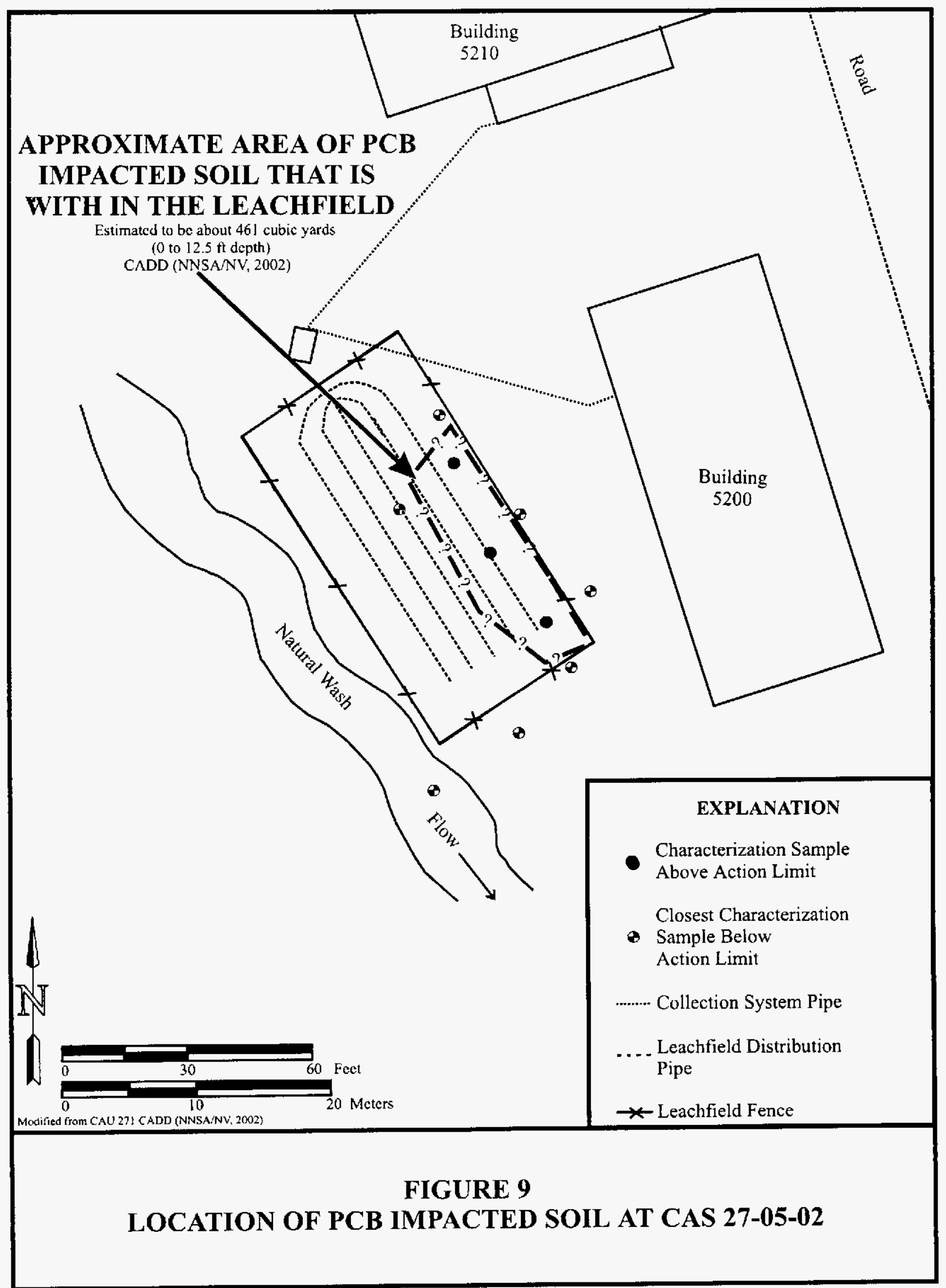


leachfield soil will be clean closed as stated in Section 2.1.2. Waste characterization sample(s) will be collected and submitted for laboratory analysis for PCB, gamma emitting radionuclides, and Isotopic Uranium. Upon receipt of the data, the waste will be disposed at an appropriate facility.

If any leachfield piping is encountered during excavation activities, a characterization sample will be collected from the material in the piping. This sample will be analyzed for VOC, SVOC, TPH, RCRA metals, PCB, gamma emitting radionuclides, Isotopic Uranium, and Isotopic Plutonium.

\subsection{CONSTRUCTION QUALITY ASSURANCE/QUALITY CONTROL}

Construction activities consist of excavation and earth moving. Permeability and compaction testing will not be necessary. As a result, construction Quality Assurance (QA)/Quality Control (QC) requirements are not required.

\subsection{WASTE MANAGEMENT}

\subsubsection{Waste Minimization}

All work activities that generate waste will follow the Bechtel Nevada (BN) Waste Minimization and Pollution Prevention Program. Special care will be given to segregate the waste streams to avoid the generation of additional waste.

All wastes will be accumulated, stored, analyzed, and disposed according to applicable state and federal regulations, U.S. Department of Energy orders, U.S. Department of Transportation requirements, and $\mathrm{BN}$ Waste Management procedures.

To restrict access to waste, a WAA will be constructed and identified with the appropriate sign. The WAA will be inspected weekly to ensure that all containers are intact and not leaking.

Approved containers will be used for HW, MW, LLW. Petroleum hydrocarbon waste will be loaded into tucks and transported to the Area 6 Hydrocarbon Landfill. After a waste container is filled, the package will be closed according to BN Organization Procedure (OP)-2151.304, "Radioactive Waste Tracking, Handling, and Management at the NTS" (BN 2000c), if applicable. If a container is not completely filled at the end of a workday, the lid will be closed and tamper-indicating tape, tag, or a lock placed on the container.

Appropriate labels will be affixed to all waste containers and relevant information will be marked on each label with an indelible marker. The information will be legible and clearly visible for inspections. Containers will be labeled with information including:

- Radiologic tracking label, HW label, or drum identification number, as appropriate

- Waste type in container 
- Waste origin

- Accumulation dates

- A "pending analysis" sticker, if sampling is required

- The words "Hazardous Waste" with containers of HW and MW

To assure container integrity, all containers will be physically inspected prior to being shipped offsite and at the time of unloading at the disposal designation.

\subsubsection{Waste Streams}

Closure activities are expected to generate sanitary, hydrocarbon-impacted, LLW, and PCB waste, but MW may also be generated. Personal Protective Equipment (PPE) that becomes contaminated during closure activities shall be disposed with the appropriate waste stream.

\subsubsection{Sanitary Waste}

Solid sanitary wastes (e.g., PPE, general trash) will be disposed in the NTS Area 23 Sanitary Landfill.

\subsubsection{Hydrocarbon Waste}

All solidified hydrocarbon waste shall be analyzed for gamma emitting radionuclides by either ISOCS analysis or laboratory analysis. Upon receipt of the analytical results, the waste will be properly classified and disposed. Any waste meeting the Land Disposal Restrictions (LDRs) as specified in the landfill permit will be disposed in the Area 6 Hydrocarbon Landfill.

Hydrocarbon waste not meeting the LDRs will be stored in the WAA until a disposal path is identified. The waste will then be disposed in a appropriate off-site.

\subsubsection{Mixed Waste}

MW may be generated during closure activities and will be managed and disposed according to all applicable BN and NNSA/NSO procedures and regulations.

\subsubsection{Low-Level Radioactive Waste}

The LLW generated during closure activities shall be managed and disposed according to all applicable regulations. Any waste determined to be radiologically impacted will be packaged in approved containers and staged in a Radioactive Materials Area for transport to an appropriate facility.

\subsubsection{PCB Waste}

PCB waste will be produced by the closure of CAS 27-05-02. Polychlorinated biphenyls are classified by the Toxic Substances Control Act as a toxic waste and will be managed as such. All work shall follow the Title 40 Code of Federal Regulations 761, "Polychlorinated Biphenyls Manufacturing, Processing, Distribution in Commerce, and Use Prohibitions (U.S. Environmental Protection Agency [EPA], 2001). The waste will be accumulated on-site in a WAA, and waste characterization samples will be collected. Upon receipt of the analytical results, the waste will be properly classified and disposed in an appropriate toxic waste Treatment, Storage, and Disposal (TSD) facility. 


\subsubsection{Hazardous Waste}

Hazardous waste may be generated during site closure activities at CASs that were previously determined to contain hazardous components. Any waste determined to be hazardous, shall be transferred to the Area 5 HW Storage Pad, and disposed at an appropriate permitted TSD facility.

\subsubsection{Decontamination Fluids}

Any equipment that becomes contaminated during closure activities will be decontaminated onsite. For larger pieces of equipment that can not be decontaminated over a 208-L (55-gal) drum, a decontamination pad will be constructed by lining a bermed area large enough to hold the heavy equipment. The equipment will be driven onto the pad and cleaned by using a pressure washer/steam cleaner or rinsed. Rinsate will be mixed with clean fill and solidified. Smaller equipment and/or tools will be decontaminated with a solution of Alconox ${ }^{\mathrm{TM}}$ and water over 208-L (55-gal) drums and solidified in the drums. The waste will be characterized. Upon receipt of analytical results, the waste will be properly classified and disposed. If a decontamination pad is constructed, upon completion of closure activities, the plastic liner will be radiologically surveyed and or sampled for PCB contamination, if applicable. The liner will be disposed in the appropriate disposal facility.

All radiologically impacted equipment and materials used at the CASs will be radiologically surveyed prior to release from the site, and all equipment and materials used at CAS 27-05-02 that are impacted with PCB shall be decontaminated/disposed of as stated in Title 40 Code of Federal Regulations 761, "Polychlorinated Biphenyls Manufacturing, Processing, Distribution in Commerce, and use Prohibitions (EPA, 2001).

\subsection{CONFIRMATION OF CORRECTIVE ACTIONS}

Accurate and defensible analytical data will be collected to verify that closure activities meet the project-specific requirements as outlined in this CAP. At the CASs where the septic tank and/or distribution box will be backfilled, verification samples will be collected from rinsate water to verify that COC have been removed. At the CASs where the septic tank and or distribution box will be removed, verification samples will be collected from the excavation to verify that COC, in the soil are not above applicable action levels. All samples will be collected by trained BN Environmental Restoration (ER) personnel and will follow BN Organization Instruction (OI)2152.108, "Soil Sampling" (BN 2000b). Immediately after collection, samples will be placed on ice and cooled to 4 degrees Celsius (39 degrees Fahrenheit). All samples will then be logged onto the Chain of Custody and transferred to the BN Analytical Services Group under strict chain-of-custody procedures OI-2152.100 "Sampling Chain of Custody" (BN 2000a). Samples will be analyzed by EPA approved analytical methods (EPA, 1996), and at EPA approved laboratories. Analytical results will be validated at the laboratory using stringent QA and QC procedures. All sample data will also be internally validated by $\mathrm{BN}$ personnel using the majority of Tier $\amalg$ validation procedures. Any data determined not to be valid will be identified in the Closure Report (CR). 
All sample data will be documented in a field logbook at the time of sample collection. The logbook will be bound with sequentially numbered pages. Entries into the logbook will include the following information:

- Names of sampling personnel

- Dates and times of samples collected

- Sample naming convention

- Sample location map including sample name, analysis, area dimensions, and permanent points of reference, if applicable

- Description of sample collected

- Sample container type, volume, preservatives (if applicable)

- Special conditions observed during sample collection (e.g., stained soil)

All field notes will be recorded in black, indelible ink. Any errors will be crossed out with a single line, initialed, and dated. All samples will be labeled with a unique sample identification number. This sample number will contain the CAS number in addition to the sample number. For example, for CAS 25-04-01, verification sample number one would be labeled 250401-V1.

One set of QAVQC samples will be collected for every 20 normal environmental samples. QA/QC samples will include blind duplicates, matrix spike/matrix spike duplicates, rinse blanks, and one trip blank for each volatile organic compound shipment. The blind duplicates will be labeled with their sample number.

\subsection{PERMITS, PLANNING, AND SITE PREPARATION}

Prior to beginning corrective action field activities, planning documents and permits will be prepared. These documents will include a Site-Specific Health and Safety Plan (SSHASP), Field Management Plan (FMP), National Environmental Policy Act (NEPA) Checklist, NNSA/NSO Real Estate/Operations Permit (REOP), Radiological Work Permits (RWP), Work Packages, utility clearance, and excavation permits.

\subsubsection{Site-Specific Health and Safety Plan}

A SSHASP (including a Preliminary Hazard Analysis and Hazard Assessment) will be prepared and a copy will be maintained on-site by the BN ER Health and Safety Officer (HSO). The SSHASP will be reviewed and signed by all workers prior to beginning work. The HSO will also maintain a material safety data sheet file for all chemicals brought to the site. The SSHASP will provide a detailed, job-specific plan covering physical and environmental hazards, protection against accidents, and exposure of workers to contamination. It will also discuss weather and air monitoring, accident reporting, and emergency procedures. Additional copies of the SSHASP will be filed in the BN ER and Environment, Safety, and Health Division offices in Mercury, Nevada. 


\subsubsection{Field Management Plan}

An FMP will be prepared for the closure activities. The FMP will include an integrated safety management plan. It will also identify the responsible parties for each aspect of the project and will indicate how decisions are to be made. Copies of the FMP will be available at each site and will be filed in the BN ER office in Mercury, Nevada.

\subsubsection{National Environmental Policy Act Checklist}

A NEPA Checklist will be completed prior to all excavation activities at the site. Excavation activities will follow all applicable federal, state, and local laws; regulations; and permits regarding protection of the environment.

\subsubsection{NNSANSO Real Estate/Operations Permit}

A REOP will be obtained prior to beginning closure activities. The permit will establish the NNSA/NSO as the prime authority possessing control of the site and will accomplish the following:

- Establish a sole governing organization responsible for safety.

- Identify NNSA/NSO's responsibility to plan and schedule activities.

\subsubsection{Radiological Work Permit}

RWPS will be prepared and approved for the purpose of informing workers of the specific PPE necessary to protect them while performing their tasks. The workers will be required to read the permits and acknowledge their understanding of the requirements before entry into the exclusion zone (EZ). The RWPs will be maintained by the Radiological Control personnel at the entrance to the site. All site workers will be required to be Radiation Worker II trained to perform any work within a Radiological Controlled Area.

\subsubsection{Utility Clearances and Excavation Permits}

A utility clearance will be performed and an excavation permit will be obtained prior to beginning any excavation activities. A copy of the permit will be filed on-site throughout the duration of the project.

\subsubsection{Site Control}

Care will be taken to minimize personnel exposure to contamination. Only properly trained personnel wearing appropriate PPE shall be allowed in the work zones. At radiologicallyimpacted sites, a hotline will be established whenever an RWP is required. This control shall serve to prevent the spread of radiological contamination outside of impacted areas. Only 
properly trained personnel wearing appropriate PPE will be allowed to enter the EZ. All equipment and materials will be radiologically surveyed by Radiological Control personnel prior to removal from the EZ. The SSHASP will specify in detail the measures that will be implemented to reduce the spread of contamination at each site.

\subsubsection{Personnel Training}

All personnel will be required to read and understand the SSHASP prior to working at the site. A tailgate safety briefing will be conducted every day prior to beginning work, or as the scope of work or site conditions change. All personnel responsible for packaging LLW or MW will be required to read and understand BN OP-2151.304, "Radioactive Waste Tracking, Handling, and Management at the NTS" (BN, 2000c). In addition, all personnel working in an EZ under a RWP will have Radiation Worker II training. Additional training requirements will be specified in the CAU 271 SSHASP. 


\subsection{SCHEDULE}

The NNSANSSO requires that all field activities be completed in Fiscal Year 2004. Preparation activities will occur during October 2003, and field work is planned to start in November 2003. The FFACO deadline for the CR is August 31, 2004 (Figure 10). Sufficient flexibility has been incorporated into the field schedule to allow for minor difficulties (e.g., weather, equipment failure). The NNSA/NSO shall notify the Nevada Division of Environmental Protection of any condition or event that may impact the project schedule. 


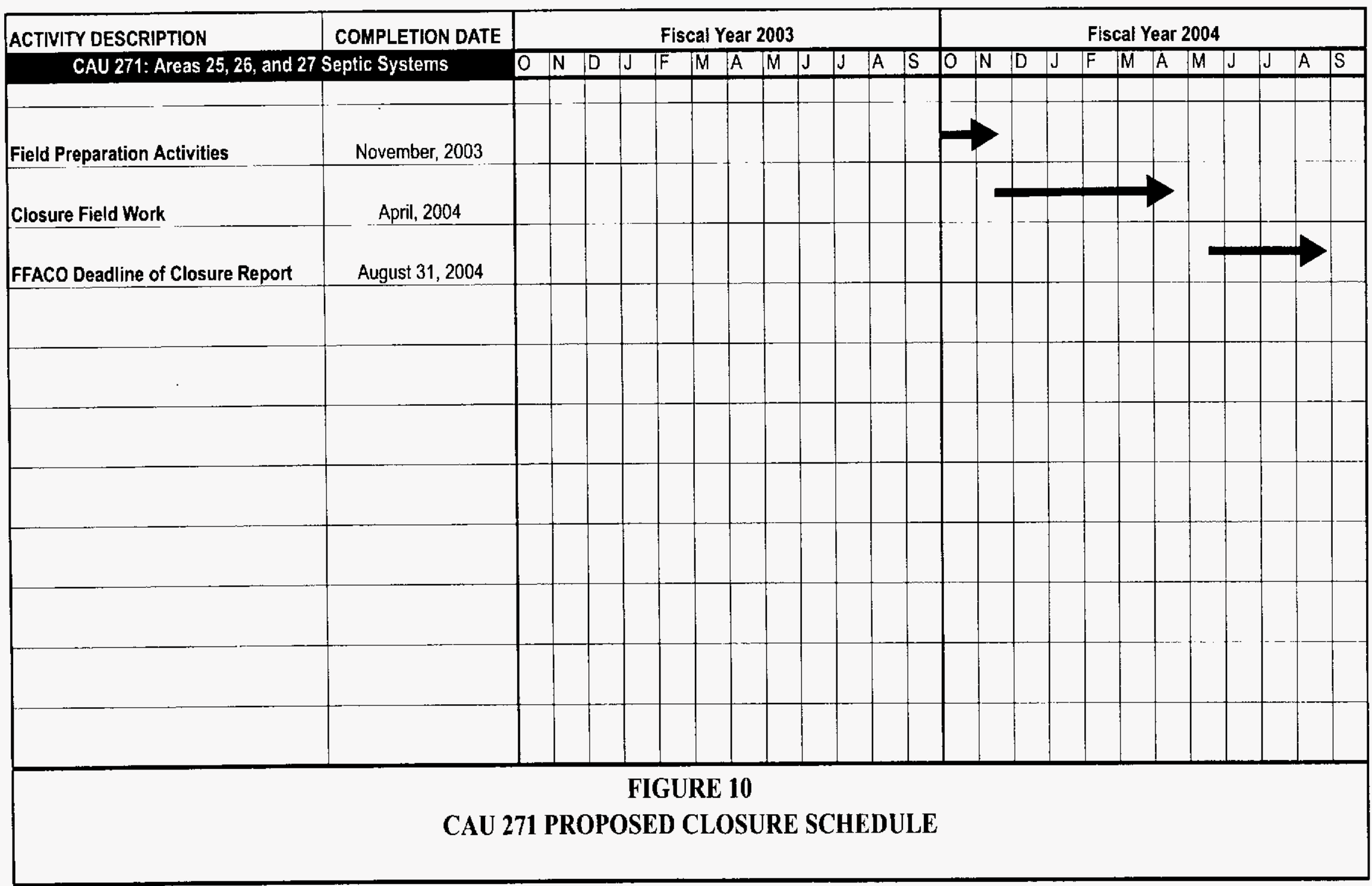




\subsection{POST-CLOSURE MONITORING PLAN}

The following 14 CASs in CAU 271 will be closed by Corrective Action Alternative 2 - Clean Closure; no post-closure monitoring is required.

- CAS 25-04-01, Septic System

- CAS 25-04-03, Septic System

- CAS 25-04-04, Septic System

- CAS 25-04-08, Septic System

- CAS 25-04-09, Septic System

- CAS 25-04-11, Septic System

- CAS 26-03-01, Contaminated Water Reservoir

- CAS 26-04-01, Septic System

- CAS 26-04-02, Septic System

- CAS 26-05-01, Radioactive Leachfield

- CAS 26-05-03, Septic System

- CAS 26-05-04, Septic System

- CAS 26-05-05, Septic System

- CAS 27-05-02, Leachfield

CAS 25-04-10, Septic System, will be closed by Corrective Action Alternative 1 - No Further Action; no post-closure monitoring is required.

\subsection{INSPECTIONS}

Inspections are not required at any CAS in CAU 271.

\subsection{MONITORING}

Post-closure monitoring is not required at any CAS in CAU 271.

\subsection{MAINTENANCE AND REPAIR}

Post-closure maintenance/repair is not required at any CAS in CAU 271. 
Section: Post Closure-Monit.

Revision: 0

Date: May 2003

THIS PAGE INTENTIONALLY LEFT BLANK 


\subsection{REFERENCES}

Bechtel Nevada. 2000a. Organization Instruction OI-2152.100, "Sampling Chain Of Custody," Rev. 0, Las Vegas, NV.

Bechtel Nevada. 2000b. Organization Instruction OI-2152.108, "Soil Sampling," Rev. 0, Las Vegas, NV.

Bechtel Nevada. 2000c. Organization Procedure OP-2151.304, "Radioactive Waste Tracking, Handling, and Management at the NTS," Rev. 2, Las Vegas, NV.

BN, see Bechtel Nevada.

EPA, see U.S. Environmental Protection Agency

Federal Facility Agreement and Consent Order. 1996 (as amended). Agreed to by the Nevada Division of Environmental Protection, the U.S. Department of Energy, and the U.S. Department of Defense.

FFACO, see Federal Facility Agreement and Consent Order.

NAC, see Nevada Administrative Code.

Nevada Administrative Code. 2002. 445A.2272, "Contamination of Soil: Establishment of Action Levels." Carson City, NV.

NNSA/NV, see U.S. Department of Energy, National Nuclear Security Administration Nevada Operations Office

U.S. Department of Energy, National Nuclear Security Administration Nevada Operations Office. 2001. Corrective Action Investigation Plan for Corrective Action Unit 271: AREAS 25, 26, AND 27 SEPTIC SYSTEMS, DOE/NV--704, Las Vegas, NV.

U.S. Department of Energy, National Nuclear Security Administration Nevada Operations Office. 2002. Corrective Action Decision Document for Corrective Action Unit 271: AREAS 25, 26, AND 27 SEPTIC SYSTEMS, Nevada Test Site, Nevada, DOE/NV--838REV 0, Las Vegas, NV.

U.S. Environmental Protection Agency. 1996. Test Methods for Evaluating Solid Waste, Physical/Chemical Methods, SW-846 CD ROM PB97-501928GEI, which contains updates for 1986, 1992, 1994, and 1996. Washington D.C. 
U.S. Environmental Protection Agency. 2001. Title 40 Code of Federal Regulations 761 , "Polychlorinated Biphenyls (PCB) Manufacturing, Processing, Distribution in Commerce, and use Prohibitions." Washington, D.C. 


\section{APPENDIX A.1}

\section{ENGINEERING SPECIFICATIONS AND DRAWINGS}


CAP - CAC 271

Section: Appendix A.1

Revision: 0

Date: May 2003

\section{THIS PAGE INTENTIONALLY LEFT BLANK}


Appendix A.1 of the standardized outline for a FFACO Corrective Action Plan, Engineering Specifications and Drawings, is not applicable to the closure of CAU 271. The CASs will be closed by Corrective Action Alternative 2 - Clcan Closure and Corrective Action Alternative 1 - No Further Action. No engineering specifications or drawings are required or necessary for closure of CAU 271. 
CAP - CAU 271

Section: Appendix A.1

Revision: 0

Datc: May 2003

THIS PAGE INTENTIONALLY LEFT BLANK 


\section{APPENDIX A.2}

\section{SAMPLING AND ANALYSIS PLAN}


CAP - CAU 271

Section: Appendix A.2

Revision: 0

Date: May 2003

THIS PAGE INTENTIONALLY LEFT BLANK 


\section{ACRONYMS AND ABBREVIATIONS}

CADD Corrective Action Decision Document

CAS Corrective Action Site

CAL Corrective Action Unit

COC contaminant(s)of concern

CSM conceptual site model

DQI Data Quality Indicators

DQO Data Quality Objective

EPA U.S. Environmental Protection Agency

NNSA/NV U.S. Department of Energy, National Nuclear Security Administration Nevada Operations Office

PCB polychlorinated biphenyls

QA Quality Assurance

QC Quality Control

TPH total petroleum hydrocarbon 
CAP - CAU 271

Section: Appendix A.2

Revision: 0

Date: May 2003

THIS PAGE INTENTIONALLY LEFT BLANK

A.2-ii 


\section{SAMPLING AND ANALYSIS PLAN FOR CORRECTIVE ACTION UNIT 271: AREAS 26, 26, AND 27 SEPTIC SYSTEMS, NEVADA TEST SITE, NEVADA}

The overall objective of the activities described in this plan is to provide data quality objectives (DQO) and conceptual site models (CSMs) which are reconciled with the models presented in the Corrective Action Decision Document (CADD) (U.S. Department of Energy, National Nuclear Security Administration Nevada Operations Office [NNSA/NV], 2002). The following sections discuss DQO which are reconciled with the models presented in the CADD (NNSA/NV, 2002), the collection of verification samples at each Corrective Action Site (CAS), the Quality Assurance (QA)/Quality Control (QC) criteria as determined in the DQO process, and the laboratory analytical Data Quality Indicators (DQI).

\subsection{RECONCILIATION OF CONCEPTUAL SITE MODELS}

This section provides a reconciliation of the data collected and analyzed in the CADD (NNSA/NV, 2002) with the CSMs established in the DQO process.

\subsection{Conceptual Site Models}

Two CSMs can be applied to the CASs in Corrective Action Unit (CAU) 271 based on data presented in the approved CADD (NNSA/NV, 2002).

The first CSM applies to all of the CASs in CAU 271, except CAS 26-03-01. These CASs will be clean closed by removing or filling the septic tanks and distribution boxes with an inert material and excavating the impacted soil identified by the CADD (NNSA/NV, 2002). Integrity soil samples presented in the CADD (NNSA/NV, 2002) indicated that none of the septic system structures (tanks, distribution boxes, and associated piping) served as a source for the release of contaminants of concern (COC) into the surrounding and underlying soil. Based on this data, this CSM assumes that the septic tanks, associated piping, and distribution boxes at the CASs are all intact and that COC have not leaked into the surrounding soil from these sources

(Figure A.2-1).

The second CSM applies to CAS 26-03-01, Contaminated Water Reservoir. This CAS will be clean closed by excavating the contaminated soil and plastic liner. This CSM assumes, based on data from the CADD (NNSA/NV, 2002), that the COC are located in the first $0.15 \mathrm{~m}(0.5 \mathrm{ft})$ of soil above the plastic liner and are contained within the confines of the reservoir berms (Figure A.2-2). 


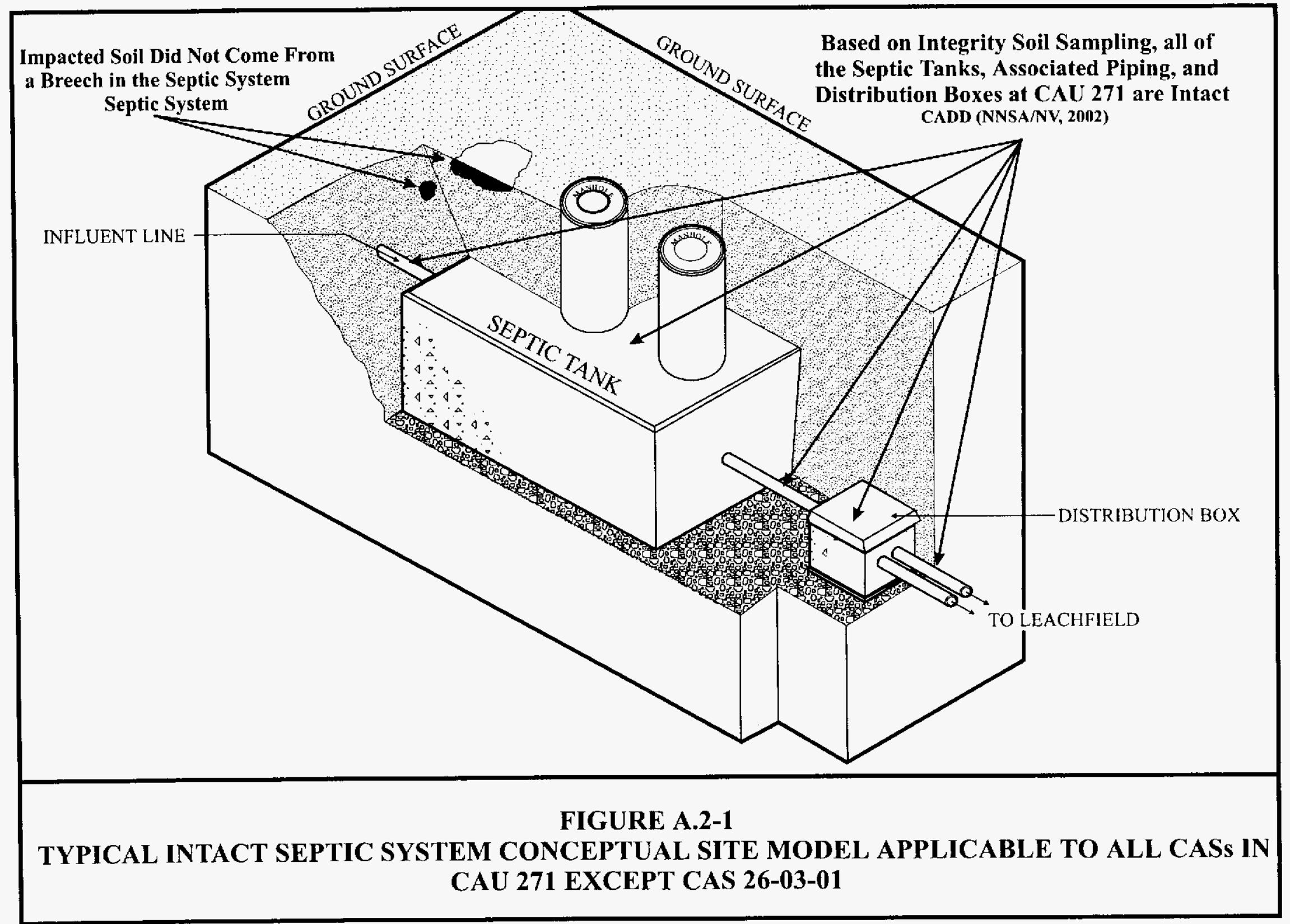




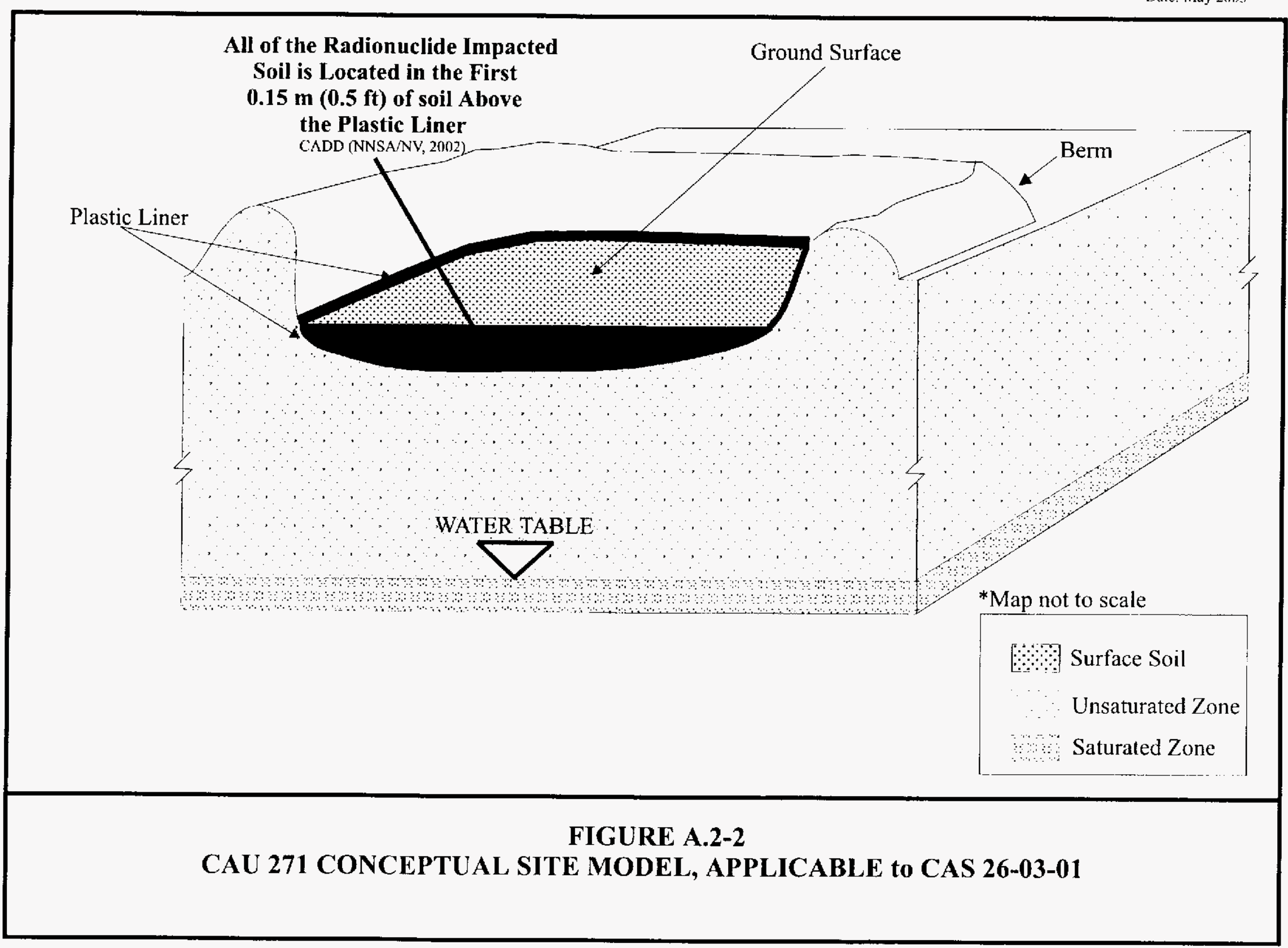




\subsection{VERIFICATION SAMPLE COLLECTION ACTIVITIES}

Once the impacted tanks, distribution boxes, and soil are removed, a minimum of five verification soil samples will be collected from each excavation. The verification samples will be submitted for laboratory analysis for all COC found at that CAS. Table A.2-1 lists the COC found at each CAS, the minium number of environmental verification samples that will be collected, and the analysis that will be performed on each sample. If verification sample results indicate any action level is exceeded, additional soil will be removed and more verification samples will be taken. These samples will provide data to verify that all COC above the preliminary action level have been removed. In addition to the field verification samples, verification QC samples will be collected in accordance with established procedures (Bechtel Nevada, 2000). Verification QC samples are collected and analyzed to establish the validity of the sample results. The number of required QC samples depends on the type and number of environmental samples collected. The minimum frequency of collecting and analyzing QC samples for this investigation, as determined in the DQO process, include:

Field duplicates ( 1 per 20 environmental samples or 1 if less than 20 are collected)

Matrix spike/matrix spike duplicate ( 1 per 20 environmental samples or 1 if less than 20 are collected)

Additional QC samples may be substituted, based on site conditions, at the discretion of the Technical Lead. Field QC samples will be analyzed using the same analytical procedures used for environmental samples. The results of the QC sample analysis will be included in the CR.

\subsection{LABORATORY/ANALYTICAL DATA QUALITY INDICATORS}

Criteria for site closure requires laboratory analysis of samples used to provide a quantitative measurement of any COCs present. Rigorous QA/QC will be implemented for all laboratory samples and will include documentation, data verification, validation of analytical results, and will meet the requirements of DQIs as they relate to laboratory analysis.

DQIs are qualitative and quantitative statements that specify the data requirements of a project and include precision, accuracy, representativeness, completeness, and comparability. In addition, sensitivity has been included as a DQI for laboratory analysis: The performance criteria for each indicator has been selected based on the intended use of the data, current field and analytical procedures, and instrumentation. Precision and accuracy goals have been standardized for both organic and inorganic analytes for analytical laboratories under the 


\section{FOR CAU271}

\begin{tabular}{|c|c|c|c|}
\hline CAS & $\mathrm{COC}$ & $\begin{array}{c}\text { MINIMUM } \\
\text { NUMBER OF } \\
\text { VERIFICATION } \\
\text { SAMPLES } \\
\end{array}$ & ANALYSIS METHOD \\
\hline CAS 25-04-01 & $\begin{array}{l}\text { TPH (Total Petroleum } \\
\text { Hydrocarbons) }\end{array}$ & $5-\mathrm{TPH}$ & $\mathrm{TPH}-8015 \mathrm{~B}^{\mathrm{A}}$ \\
\hline CAS 25-04-03 & TPH & $5-\mathrm{TPH}$ & $\mathrm{TPH}-8015 \mathrm{~B}^{\mathrm{A}}$ \\
\hline CAS 25-04-04 & $\begin{array}{l}\text { TPH, Radionuclides, } \\
\text { Pesticides }\end{array}$ & $\begin{array}{c}10-\text { TPH } \\
5 \text { - Isotopic Urarium } \\
5 \text { - Gamma Spec } \\
5 \text { - TCLP }{ }^{\mathrm{B}} \text { Pesticides }\end{array}$ & $\begin{array}{c}\text { TPH - 8015B } \\
\text { Isotopic Uranium - HASL - } 300 \\
\text { Gamma Spec }-901.1^{\mathrm{A}} \\
\text { Pesticides }-8081^{\mathrm{A}}\end{array}$ \\
\hline CAS 25-04-08 & TPH, Radionuclides & $\begin{array}{c}5-\text { TPH } \\
5-\text { Isotopic Plutonium }\end{array}$ & $\begin{array}{c}\text { TPH }-8015 \mathrm{~B}^{\mathrm{A}} \\
\text { Isotopic Plutonium - ASL LID }\end{array}$ \\
\hline CAS 25-04-09 & $\mathrm{TPH}$ & 5 - TPH & $\mathrm{TPH}-8015 \mathrm{~B}^{\mathrm{A}}$ \\
\hline CAS 25-04-10 & NA & NA & $\mathrm{NA}$ \\
\hline CAS 25-04-11 & TPH & $10-\mathrm{TPH}$ & TPH $-8015 B^{A}$ \\
\hline CAS 26-03-01 & Radionuclides & 5 - Garnma Spec & Gamma Spec-901. ${ }^{\mathrm{A}}$ \\
\hline CAS 26-04-01 & Radionuclides & $\begin{array}{l}\text { 5- Gamma Spec } \\
\text { 5- Isotopic Plutonium }\end{array}$ & $\begin{array}{c}\text { Gamma Spec-901.1 } \\
\text { Isotopic Plutonium - ASL LID }\end{array}$ \\
\hline CAS 26-04-02 & TPH & $5-\mathrm{TPH}$ & $\mathrm{TPH}-8015 \mathrm{~B}^{\mathrm{A}}$ \\
\hline CAS 26-05-01 & TPH, Radionuclides & $\begin{array}{c}10-\text { TPH } \\
10 \text { - Isotopic Uranium } \\
10 \text { - Isotopic Plutonium } \\
10 \text { - Gamma Spec }\end{array}$ & $\begin{array}{c}\text { TPH - 8015B } \\
\text { Isotopic Uranium - HASL - } 300 \\
\text { Isotopic Plutonium - ASL LID } \\
\text { Gamma Spec - 901.1 }\end{array}$ \\
\hline CAS 26-05-03 & TPH & $10-\mathrm{TPH}$ & $\mathrm{TPH}-8015 \mathrm{~B}^{\mathrm{A}}$ \\
\hline CAS 26-05-04 & TPH & $5 \cdot \mathrm{TPH}$ & $\mathrm{TPH}-8015 \mathrm{~B}^{\mathrm{A}}$ \\
\hline CAS 26-05-05 & TPH, Radionuclides & $\begin{array}{c}15 \cdot \text { TPH } \\
5-\text { Isotopic Uranium } \\
5 \text { - Isotopic Plutonium } \\
5 \text { - Gamma Spec }\end{array}$ & $\begin{array}{c}\text { TPH - 8015B } \\
\text { Isotopic Uranium - HASL - } 300 \\
\text { Isotopic Plutonium - ASL LID } \\
\text { Gamma Spec - 901.1 }\end{array}$ \\
\hline CAS 27-05-02 & $\begin{array}{l}\text { TPH, Radionuclides, } \\
\text { PCB (Polychlorinated } \\
\text { Biphenyls) }\end{array}$ & $\begin{array}{c}15-\text { PCB } \\
10-\text { Isotopic Uranium } \\
10-\text { Gamma Spec } \\
10-\text { TPH } \\
\end{array}$ & $\begin{array}{c}\text { PCB }-8082^{\wedge} \\
\text { Jsotopic Plutonium - ASL LID } \\
\text { Gamma Spec }-901.1^{\mathrm{A}} \\
\text { TPH }-8015 \mathrm{~B}^{\mathrm{A}}\end{array}$ \\
\hline
\end{tabular}

\footnotetext{
A U.S. Environmental Protection Agency's Test Methods for Evaluating Solid Waste, $3^{\text {rd }}$ Edition, Parts 1-4, SW-846
} (EPA, 1996)

${ }^{B}$ U.S. Environmental Protection Agency's Toxicity Characterization Leaching Procedure 


\section{U.S. Environmental Protection Agency (EPA) Contract Laboratory Program (EPA, 1988a; EPA,} 1988b). Laboratory QC samples used to measure the precision and accuracy of analytical procedures will be analyzed using the same analytical procedures used for environmental samples.

Table A.2-2 provides the established performance criteria for each of the DQIs and the impacts to the decision if the criteria are not met.

\section{TABLE A.2-2- LABORATORY/ANALYTICAL DATA QUALITY INDICATORS}

\begin{tabular}{|c|c|c|}
\hline $\begin{array}{c}\text { DATA } \\
\text { QUALITY } \\
\text { INDICATOR }\end{array}$ & $\begin{array}{l}\text { PERFORMANCE } \\
\text { CRITERIA }\end{array}$ & $\begin{array}{c}\text { IMPACT ON DECISION IF } \\
\text { PERFORMANCE CRITERIA NOT } \\
\text { MET }\end{array}$ \\
\hline Precision & $\begin{array}{l}\text { Variations between duplicates (field and lab) } \\
\text { and original sample should not excecd } \\
\text { analytical method-specific criteria. }\end{array}$ & $\begin{array}{l}\text { Estimated data within sample delivery group (SDG) will be } \\
\text { evaluated for their usability. If data are determined to be } \\
\text { unusable, data will not be used in decision and completeness } \\
\text { criteria will be assessed. }\end{array}$ \\
\hline Accuracy & $\begin{array}{l}\text { Laboratory control sample results and matrix } \\
\text { spike results should be within analytical } \\
\text { method-specific criteria. }\end{array}$ & $\begin{array}{l}\text { Estimated data within SDG will be evaluated for its usability. } \\
\text { If cstimated data are biased high or conservative, the data } \\
\text { may be used in decision. If cstimated data are biased low and } \\
\text { below the decision threshold, the data may not be used in } \\
\text { decision and completeness criteria will be assessed. }\end{array}$ \\
\hline Sensitivity & $\begin{array}{l}\text { Detection limits of laboratory instruments must } \\
\text { be less than action level for } \mathrm{COC} \text {. }\end{array}$ & $\begin{array}{l}\text { Cannot determine if COCs are present at levels of concern, } \\
\text { thereby investigation objectives cannot be met. }\end{array}$ \\
\hline Completeness & $\begin{array}{l}100 \% \text { of samples submitted to laboratory } \\
100 \% \text { of requested analyses performed } \\
100 \% \text { of critical analytes to be valid } \\
80 \% \text { of non-critical analytes to be valid }\end{array}$ & $\begin{array}{l}\text { 1. Decision of whether extent of contamination has been } \\
\text { bounded cannot be determined. Impacts to decisions will be } \\
\text { assessed. } \\
\text { 2. Decision of whether COCs (TPH) above NAC level remain } \\
\text { in soil cannot be determined. Impacts to decisions will be } \\
\text { assessed. }\end{array}$ \\
\hline Comparability & $\begin{array}{l}\text { Equivalent samples analyzed using same } \\
\text { analytical methods, same units of measurement, } \\
\text { and detcction limits must be used for like } \\
\text { analyses. }\end{array}$ & Inability to use data collected. \\
\hline Representa-tiveness & $\begin{array}{l}\text { Correct analytical method performed for } \\
\text { appropriate COC: valid data reflects } \\
\text { appropriate target population. }\end{array}$ & $\begin{array}{l}\text { Cannot identify COC or estimate concentration of COC: } \\
\text { therefore, cannot make decision(s) on target population. }\end{array}$ \\
\hline
\end{tabular}

${ }^{2}$ Critical analytes are those analytes most likely present in the target population at $\mathrm{COCs}$, which have been identified through process knowledge of similar sites and historical documentation. Critical analytes for samples are TPH, PCBs, VOCs, SVOCs, RCRA metals and various radionuclides. 


\subsection{REFERENCES}

Bechtel Nevada. 2000. Organization Instruction OI-2152.106, "Soil Sampling."

BN, see Bechtel Nevada.

EPA, see U.S. Environmental Protection Agency

NNSA/NV, see U.S. Department of Energy, National Nuclear Security Administration Nevada Operations Office

U.S. Department of Energy, National Nuclear Security Administration Nevada Operations Office. 2001. Corrective Action Investigation Plan for Corrective Action Unit 271: AREAS 25, 26, AND 27 SEPTIC SYSTEMS, DOE/NV--704, Las Vegas, NV.

U.S. Department of Energy, National Nuclear Security Administration Nevada Operations Office. 2002. Corrective Action Decision Document for Corrective Action Unit 271: AREAS 25, 26, AND 27 SEPTIC SYSTEMS, Nevada Test Site, Nevada, DOE/NV--838REV 0, Las Vegas, NV.

U.S. Environmental Protection Agency. 1988a. Contract Laboratory Program Statement of Work for Inorganic Analysis, SOW No. 788, EPA/540/R-94/093. Washington, D.C.

U.S. Environmental Protection Agency. 1988b. Contract Laboratory Program Statement of Work for Organic Analysis, SOW No. 288, EPA/540/R-94/096. Washington, D.C.

U.S. Environmental Protection Agency. 1996. Test Methods for Evaluating Solid Waste, Physical/Chemical Methods, SW-846 CD ROM PB97-501928GEI, which contains updates for 1986, 1992, 1994, and 1996. Washington D.C. 
Revision: 0

Date: May 2003

THIS PAGE INTENTIONALLY LEFT BLANK 


\section{APPENDIX A.3}

\section{PROJECT ORGANIZATION}


CAP - CAL: 271

Scction: Appendix A.3

Revision: 0

Date: May 2003

THIS PAGE INTENTIONALLY LEFT BLANK 


\section{PROJECT ORGANIZATION}

The U.S. Department of Energy, National Nuclear Security Administration Nevada Site Office (NNSA/NSO) Project Manager or Task Manager will serve as the primary point of contact for all activities conducted for this project. The NNSA/NSO Project Manager is responsible for seeing that all activities conducted during the project fulfill the obligations of NNSA/NSO, as described in the Federal Facility Agreement and Consent Order of 1996 (as amended) and the Nevada Division of Environmental Protection (NDEP) approved work plan. The NNSA/NSO Project Manager will plan, authorize, and control project work so that activities are completed according to the work plan on schedule and within the budget. The NNSA/NSO Project Manager will be the primary point of contact with the NDEP. The NNSA/NSO points of contact for this project are as follows:

NNSA/NSO Project Manager: Janet Appenzeller-Wing

Telephone Number: (702) 295-0461

NNSA/NSO Task Manager: Kevin Cabble

Telephone Number: (702) 295-5000

The identification of the project Health and Safety Officer and the Quality Assurance Officer can be found in the appropriate plan. However, personnel are subject to change and it is suggested that the appropriate DOE or DTRA Project Manager be contacted for further information. The Task Manager will be identified in the FFACO Biweekly Activity Report prior to the start of field activities. 
CAP - CAL 271

Section: Appendix A.3

Revision: 0

Date: May 2003

THIS PAGE INTENTIONALLY LEFT BLANK 


\section{APPENDIX B}

\section{NEVADA DIVISION OF ENVIRONMENTAL PROTECTION DOCUMENT REVIEW SHEET}


CAP - CALI 27I

Section: Appendix B

Revision: 0

Date: May 2003

THIS PAGE INTENTIONALLY LEFT BLANK 


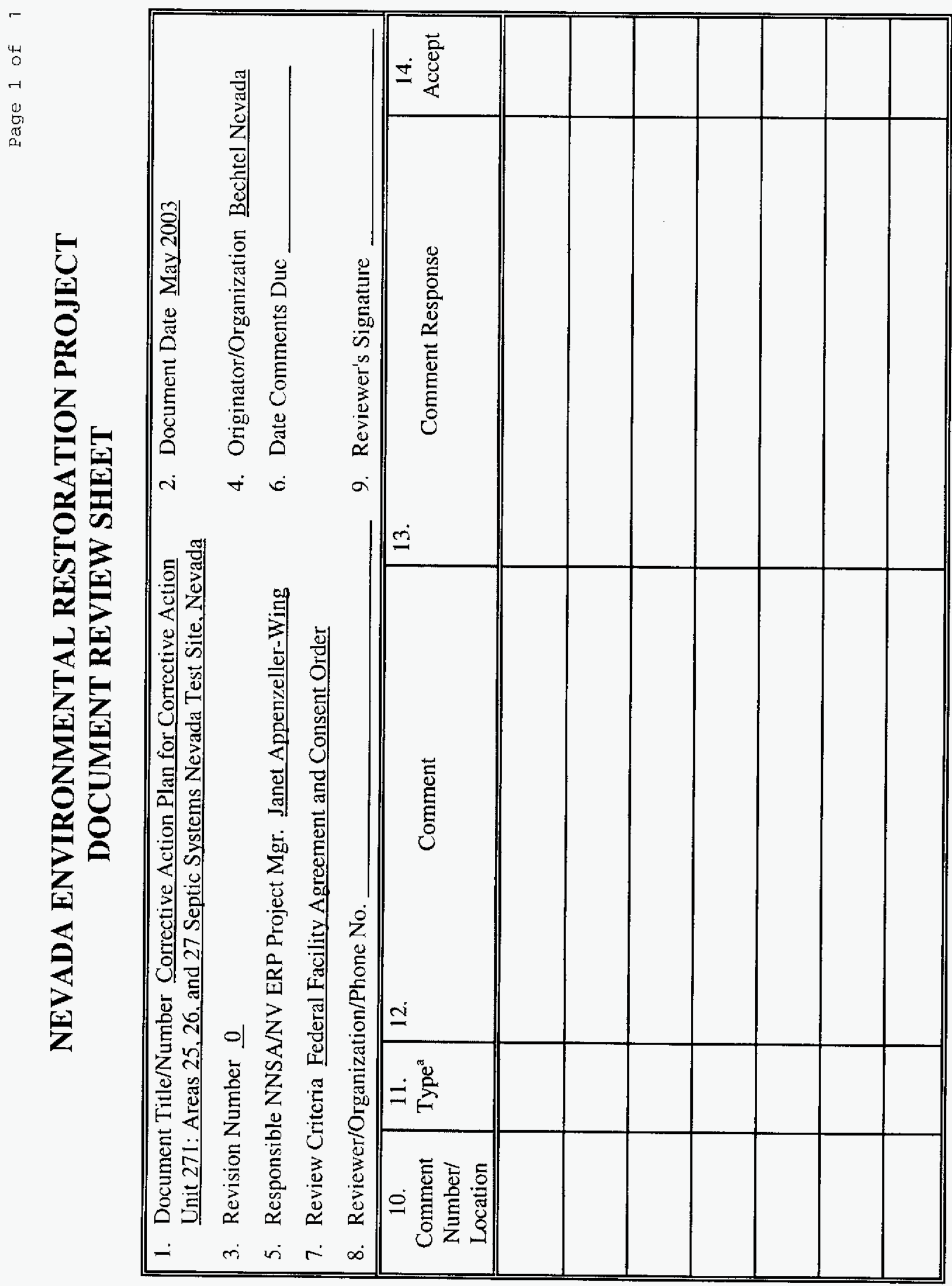

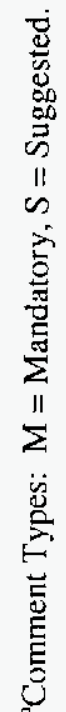


CAP - CAL 271

Section: Appendix B

Revision: 0

Date: May 2003

THIS PAGE INTENTIONALLY LEFT BLANK 
CAP - CAU 271

Section: Distribution

Revision: 0

Date: May 2003

\section{DISTRIBUTION LIST}


CAP - CAU 271

Section: Distribution

Revision: 0

Date: May 2003

THIS PAGE INTENTIONALLY LEFT BLANK 


\section{DISTRIBUTION LIST}

Provide copy of initial distribution of all revisions; others receive Nevada Division of Environmental Protection-approved revision only.

\section{Nevada Division of Environmental Protection}

Paul Liebendorfer

1 (Controlled)*

Bureau of Federal Facilities

Division of Environmental Protection

333 W. Nye Lane, Room 138

Carson City, NV 89706-0866

Donald Elle

1 (Controlled)*

Bureau of Federal Facilities

Division of Environmental Protection

1771 E. Flamingo Rd., Suite 121-A

Las Vegas, NV 89193-0837

\section{U.S. Department of Energy}

Janet Appenzeller-Wing

1 (Uncontrolled)*

Environmental Restoration Division

U.S. Department of Energy

National Nuclear Security Administration

Nevada Site Office

P.O. Box 98518 , M/S 505

Las Vegas, NV 89193-8518

Kevin Cabble

Environmental Restoration Division

1 (Uncontrolled)*

U.S. Department of Energy

National Nuclear Security Administration

Nevada Site Office

P.O. Box 98518 , M/S 505

Las Vegas, NV 89193-8518

Sabrina Lawrence

Environmental Restoration Division

1 (Controlled)*

U.S. Department of Energy

National Nuclear Security Administration

Nevada Site Office

P.O. Box 98518, M/S 505

Las Vegas, NV 89193-8518 


\section{DISTRIBUTION LIST (continued)}

\section{U.S. Department of Energy (continued)}

U.S. Department of Energy

National Nuclear Security Administration

Nevada Site Office

Public Reading Facility

P.O. Box 98521, M/S NLV040

Las Vegas, NV 89193-8521

U.S. Department of Energy

National Nuclear Security Administration

Nevada Site Office

Technical Library

P.O. Box 98518 , M/S 505

Las Vegas, NV 89193-8518

U.S. Department of Energy

Office of Scientific and Technical Information

P.O. Box 62

Oak Ridge, TN 37831-0062

\section{Bechtel Nevada}

Correspondence Control

1 (Uncontrolled)*

Bechtel Nevada

P.O. Box 98521, M/S NLV008

Las Vegas, NV 89193-8521

Environmental Management Library

1 (Uncontrolled)*

Bechtel Nevada

P.O. Box 98521, M/S NLV080

Las Vegas, NV 89193-8521

Thomas Fitzmaurice

1 (Uncontrolled)*

1 (Uncontrolled Electronic)
1 (Controlled) \&

1 (Uncontrolled)

1 (Uncontrolled)

Bechtel Nevada

P.O. Box 98521, M/S NTS306

Las Vegas, NV 89193-8521 


\section{DISTRIBUTION LIST (continued)}

\section{Bechtel Nevada (continued)}

Brad Jackson

1 (Uncontrolled)*

Bechtel Nevada

P.O. Box 98521, M/S NTS306

Las Vegas, NV 89193-8521

Wayne Johnson

1 (Uncontrolled)*

Bechtel Nevada

P.O. Box 98521, M/S NLV080

Las Vegas, NV 89193-8521

Steve Nacht

1 (Uncontrolled)*

Bechtel Nevada

P.O. Box 98521, M/S NTS306

Las Vegas, NV 89193-8521

David Nacht

1 (Uncontrolled)*

Bechtel Nevada

P.O. Box 98521, M/S NTS306

Las Vegas, NV 89193-8521

\section{Shaw Environmental, Inc.}

FFACO Coordinator

1 (Controlled)

Shaw Environmental, Inc.

7710 W. Cheyenne Ave.

Las Vegas, NV 89129

John Stokowski

1 (Uncontrolled)*

Shaw Environmental, Inc.

7710 W. Cheyenne Ave.

Las Vegas, NV 89129

\section{State of Nevada}

Manager, Northern Nevada

1 (Uncontrolled)

FFACO Public Reading Facility

Nevada State Library and Archives Federal Publications

100 North Stewart Street

Carson City, NV 89701-4285 
CAP - CAU 271

Section: Distribution

Revision: 0

Date: May 2003

THIS PAGE INTENTIONALLY LEFT BLANK 